\title{
PENICILLIN TREATMENT OF SUBACUTE BACTERIAL ENDOCARDITIS
}

\author{
BY
}

A. MORGAN JONES,* R. HERRING, F. A. LANGLEY, AND S. OLEESKY

From the Departments of Cardiology and Pathology, University of Manchester, and the Department of Clinical Pathology, Manchester Royal Infirmary

Received December 3, 1946

The early impression that penicillin was ineffective in subacute bacterial endocarditis arose from the first case treated, that of Florey and Florey (1943), and from the 17 cases unsuccessfully treated by Keefer et al. (1943). In the following year Loewe et al. (1944) recorded 7 apparently successful cases, but the period of observation was very short. More failures followed (Herrell, 1944; Herrell et al., 1944; Bloomfield et al., 1944), but Dawson and Hobby

TABLE I

Cases of Subacute Bacterial Endocarditis Treated with Penicillin: Reported between JANUARY 1945 AND AUguST 1946

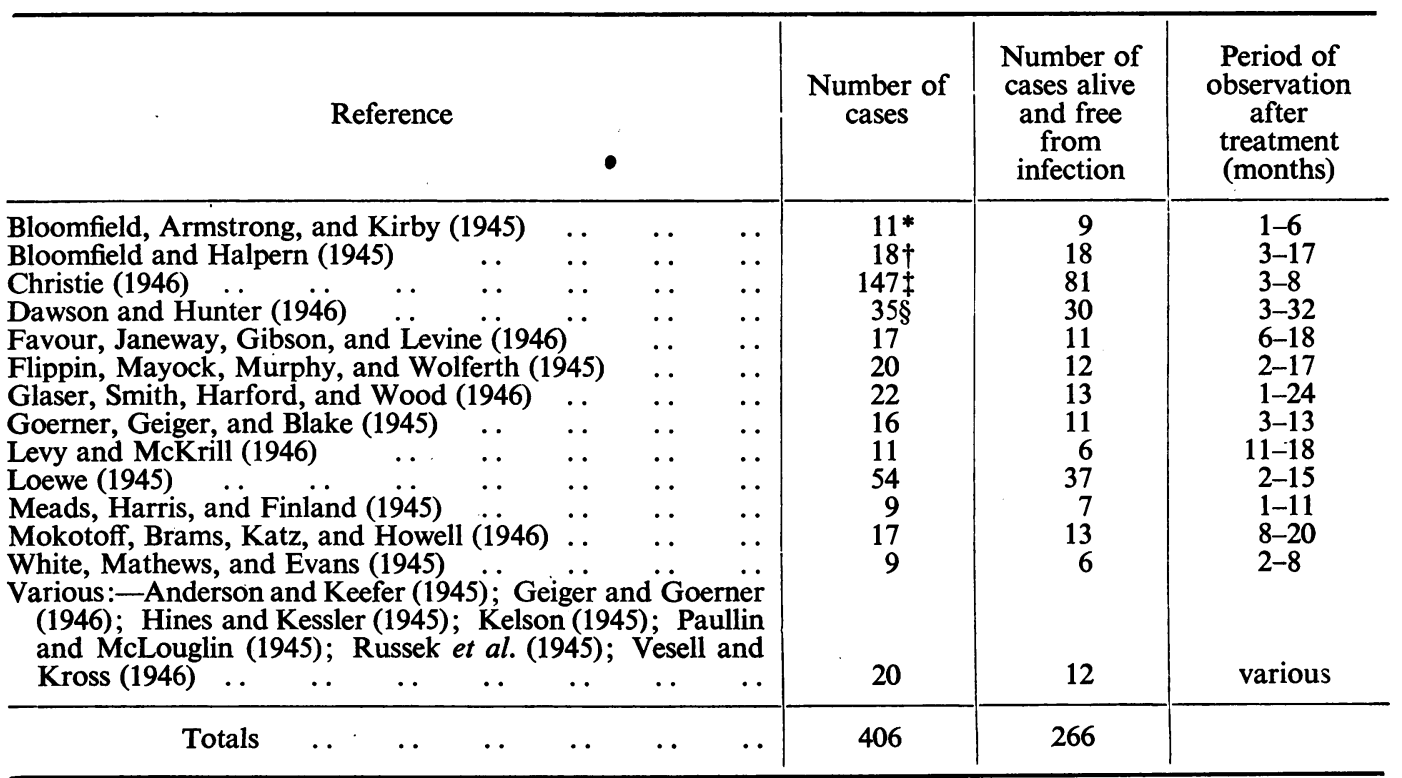

* Favourable cases selected, with 3 exceptions.

$\uparrow$ Favourable cases selected; an unstated number previously reported were included.

$\ddagger$ Collected British cases including 18 cases of Ward, Meanock, Selbie, and Simon (1946) and 20 cases of Sanderson and McEntegart (1946).

$\S$ First 5 cases selected as favourable, and 30 unselected except organism penicillin-sensitive.

* Leverhulme Research Scholar, Royal College of Physicians. 
(1944) were successful in 3 of 10 cases. At this time Keefer (1944) stated that of 55 cases treated in the United States only 3 were alive a year later.

By 1945 it was realized that to be successful penicillin must be administered in large doses for long periods; Keefer (1945) suggested 200,000 to 300,000 units daily for 3 weeks, Loewe (1945) advised up to $1,000,000$ units daily for 5 weeks and Bloomfield et al. (1945) gave 200,000 units daily for 6 to 8 weeks. The subsequent results have been considerably better and, since the beginning of 1945, reports of 406 cases with 266 recoveries have been published in this country and in the United States; these are summarized in Table I. In some instances the results are not representative of the value of penicillin in unselected cases for, owing to shortage of penicillin at the time, those likely to benefit from treatment were chosen.

Early in 1945 the Medical Research Council initiated a coordinated investigation at 12 centres in Britain, and Christie (1946) has published a summary of the results in the first 147 unselected cases with 81 recoveries. At the Manchester centre 40 have so far been treated; 7 of these, in which treatment was completed less than six months ago, are excluded. This period has been selected because in published cases, death has so far not occurred more than six months after successful treatment except from heart failure or unrelated causes. Only those in which the causative organism was isolated are included, but otherwise there has been no selection; 2 patients were moribund on admission and in 1 the infecting organism was insensitive to penicillin.

\section{Some Clinical Features Before Treatment}

Of 33 patients, 11 were male and 22 female; their ages ranged from 13 to 59.

Capacity for Effort before Infection. Subacute bacterial endocarditis rarely develops when rheumatic or congenital heart disease is severe (Libman and Friedberg, 1942); none of our patients had auricular fibrillation or a history of heart failure prior to infection and all were either in employment or looked after their homes and families or studied at school or college (Table II). In only 3 cases had there been considerable impairment of capacity for effort

TABLE II

CAPACITY FOR EFFORT AND OCCUPATION BEFORE INFECTION

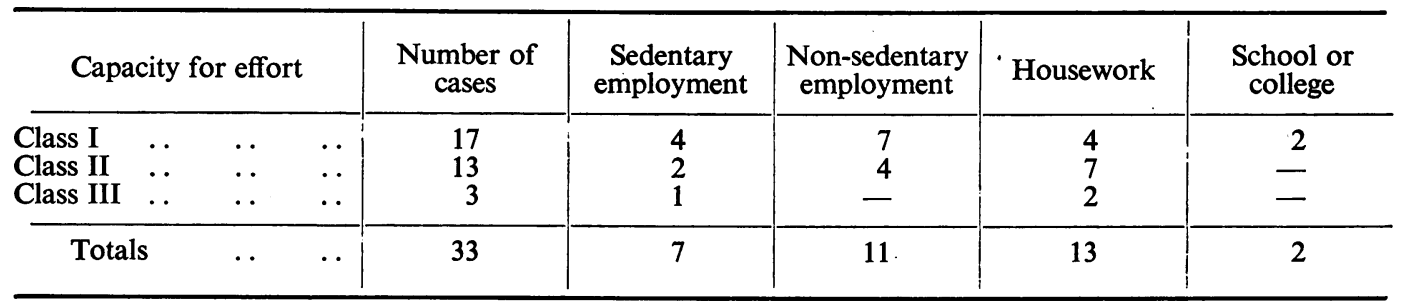

before infection (Class III); in 13 cases some dyspnœa had occurred on unusual exertion but not during ordinary activity (Class II); in 17 cases no symptoms had been noticed on exertion and 8 of these patients had been unaware of their cardiac lesion (Class I). The classification used in that accepted by the American Heart Association (Criteria for Nomenclature and Diagnosis, 1942).

Physical Signs of Underlying Heart Disease. Rheumatic heart disease was present in 28 and congenital heart disease in 4 cases; in one both congenital and rheumatic lesions were found at necropsy. In 11 of our 29 rheumatic cases only systolic murmurs were present on admission and we have been impressed by the rarity of the typical presystolic murmur when 
bacterial endocarditis is present. Although radioscopy sometimes showed pulmonary congestion and enlargement of the right ventricle consistent with well-developed mitral stenosis, we believe that the rarity of the characteristic physical signs is principally because only slight mitral lesions were present in most cases, for mitral stenosis was present in only 2 of 12 cases with rheumatic heart disease that came to necropsy. Aortic incompetence, however, appeared to be disproportionately common, for it was present clinically in 16 of 29 rheumatic cases. This high proportion may be due to the tendency for subacute bacterial endocarditis to attack the aortic valve, so that some aortic lesions may have arisen from the infection and not from the underlying rheumatic heart disease.

Thus, in this series, both the good capacity for effort before infection and the nature of the rheumatic valvular lesions support the view that the underlying heart disease was usually relatively slight.

The Onset of Bacterial Endocarditis. This occurred during pregnancy or at confinement in 7 cases, nearly one-third of our female cases. In 3 cases symptoms of infection were first noticed, two, six, and nine weeks after dental extractions.

The initial symptoms of bacterial endocarditis rarely give any indication of the nature of the infection (Christian, 1941); in our cases the commonest presenting features were lassitude (10 cases), generalized " rheumatic" pains (6), pyrexia in patients already under observation (6), or a vague illness resembling influenza (5 cases). In 3 cases major embolic accidents marked the onset of symptoms; in one a subarachnoid hæmorrhage was presumably due to rupture of a mycotic cerebral aneurysm; in a second hæmoptysis from a pulmonary infarct led to a mistaken diagnosis of pulmonary tuberculosis, and in the third visible hæmaturia and loin pain from a large renal infarct suggested the presence of a urinary calculus. Persistent sweating (twice) and pallor (once) were the presenting symptoms in the other 3 cases.

The subsequent symptoms were protean. Loss of weight occurred in every case but was often not noticed until several months after the onset of the infection. Generalized " rheumatic" pains developed at some stage in 17 cases. These pains were sudden in onset but fleeting in character; they were rarely confined to the joints but often affected muscle masses in the limbs or trunk. They sometimes led to a mistaken diagnosis of "rheumatism" or rheumatic fever. Pain persisting in one site, presumably embolic in origin, was noticed in 21 cases; in 9 in a limb, in 5 in the splenic area, in 4 in the chest, in 2 in the lumbar area and in 1 severe central abdominal pain persisted for several weeks. Nausea and vomiting were common, and persistent sweating was noticed in 15 and rigors in 4 cases. Progressive impairment of capacity for effort was a feature in 16 and was followed by heart failure in 15; this was usually a late feature of cases in which the diagnosis was delayed.

In over one-third of our cases (13) symptoms had been present for twenty or more weeks before treatment.

In addition to the 3 cases in which symptoms of bacterial endocarditis followed dental extraction, teeth were extracted after the onset of bacterial endocarditis in 2 others, and paradontal sepsis was present in 9 others. Tonsillar sepsis was found in 4 and cholecystitis in 1 case. The frequency of paradontal and tonsillar sepsis in this series supports the suggestion that the mouth and pharynx are often the sites from which the cardiac infection arises but, since Strept. viridans can be grown from the normal mouth, it did not seem worthwhile to attempt to compare the organism grown from the blood with the flora of the mouth and pharynx.

Sulphonamides had been given to 15 cases before admission; in all these the causative organism was subsequently isolated from the blood. 


\section{INVESTIGATIONS}

The scheme of investigation is detailed in Table III.

Blood Cultures were made without regard to the temperature of the patient by the method of Penfold, Goldman, and Fairbrother (1940): 7 c.c. of blood was withdrawn from a vein into a sterile oil-free syringe; 2 c.c. was introduced into a small vial containing a balanced oxalate mixture (Wintrobe and Landsberg, 1935) and reserved for the erythrocyte sedimentation rate; 1 c.c. was added to 4 c.c. glucose trypsin broth and 1 c.c. to 4 c.c. saponin broth; with these pour plates were made using melted agar. The remaining 3 c.c. was added to 50 c.c. of Hartley digest broth. The inoculated media were incubated at $37^{\circ} \mathrm{C}$. under atmospheric conditions and kept 14 days before a final negative report was given. If negative, further cultures were incubated in an atmosphere of 10 per cent $\mathrm{CO}_{2}$ as it was found that several strains grew more readily, or could only be grown, under these conditions: this technique was later adopted in all cases. To cultures taken during penicillin therapy sufficient penicillinase (prepared by the method of Duthie, 1944) was added to neutralize a concentration of at least 10 units of penicillin per c.c. of blood.

TABLE III

SCHEME OF INVESTIGATION

\begin{tabular}{|c|c|c|}
\hline Before treatment & During treatment & After treatment \\
\hline $\begin{array}{l}\text { Cardioscopy } \\
\text { Cardiogram } \\
\text { Blood culture } \\
\text { Full blood count } \\
\text { Sedimentation rate } \\
\text { Microscopy urinary deposit } \\
\text { Urea clearance } \\
\text { Blood urea } \\
\text { Bacteriology of urine }\end{array}$ & 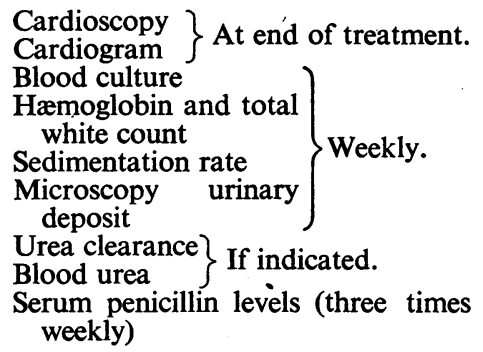 & $\begin{array}{l}\text { Cardioscopy } \\
\text { Cardiogram At intervals. } \\
\text { Blood culture } \\
\text { Hæmoglobin and } \\
\left.\left.\begin{array}{l}\text { total white count } \\
\text { Sedimentation rate } \\
\text { Microscopy urinary } \\
\text { deposit }\end{array}\right\} \begin{array}{l}\begin{array}{l}\text { In first week; } \\
\text { every two weeks }\end{array} \\
\begin{array}{l}\text { a p y r e x i a 1 ; } \\
\text { monthly after } \\
\text { discharge. }\end{array} \\
\text { Blood urea }\end{array}\right\} \begin{array}{l}\text { If previously } \\
\text { abnormal. }\end{array}\end{array}$ \\
\hline
\end{tabular}

In 16 of 33 cases positive blood cultures had been obtained before admission, in 5 repeated cultures had been negative, and in 12 no culture had been attempted. On admission a positive culture was obtained at the first attempt in 29 and on the second attempt in the remaining 4 cases. In only one, admitted with suspected bacterial endocarditis during this investigation, were we unable to isolate an organism; that case is, therefore, not included in this series. Using the technique we have described it is rare to encounter difficulty in isolating the organism in clinical cases of bacterial endocarditis.

Strept. viridans was isolated in 26 and non-hæmolytic streptococci in 5 cases; in 1 of the remaining 2 the organism was Hamophilus influenze and in the other case a Pneumococcus was isolated.

TABLE IV

Coefficients of Resistance of Infecting Organisms

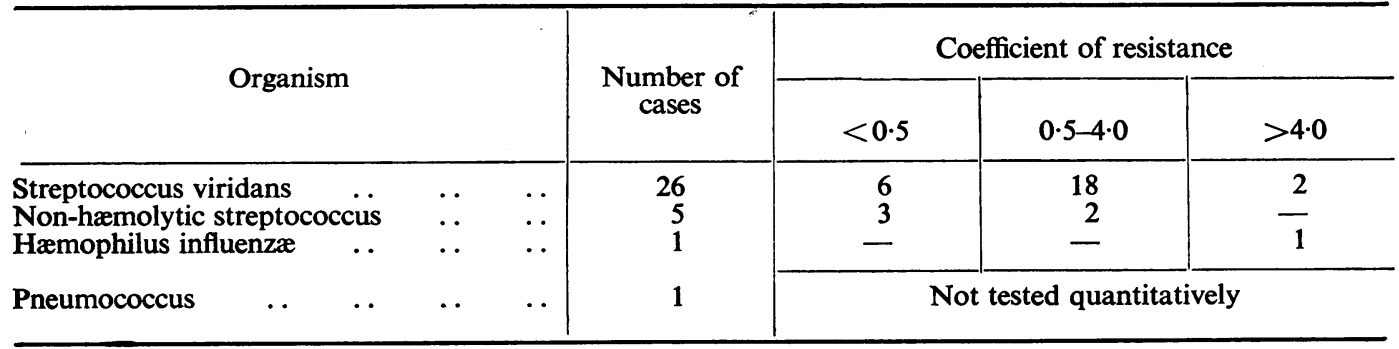


Coefficients of Resistance of the Organisms. Two sets of tubes were prepared with twofold decreasing dilutions of a nutrient broth containing a known concentration of penicillin. Each tube of one set was inoculated with a standard drop of a 24-hour broth culture of Staph. pyogenes (Oxford " $H$ " strain) and to each tube of the other set a drop of a broth suspension of the test organism was added. All tubes were incubated overnight and the resistance of the organism to penicillin estimated by comparing the concentration of penicillin necessary to inhibit its growth with the concentration that inhibited growth of the Oxford staphylococcus; the resistance of the test organism was expressed as a multiple of the resistance of the Oxford staphylococcus. Our observations are summarized in Table IV.

Penicillin Serum Levels. The penicillin level in the blood was estimated in a similar way, but in one set of tubes the patient's serum was used instead of the penicillin solution and all tubes were inoculated with the Oxford staphylococcus. The bacteriostatic activity of the patient's serum was thus compared with that of known concentrations of penicillin.

These methods of estimating the resistance of the organism and the penicillin serum level are open to criticism. Although standard solutions of penicillin do not contain less than the stated amount, they may contain rather more and this will lead to an underestimate of the penicillin serum level. The penicillin sensitivity of the Oxford staphylococcus varies in subculture and is not an altogether reliable standard for assessing the resistance of the test organism. Similar difficulties have been encountered by Glaser $e$ t al. (1946). The principal value of these tests lies in their ability to recognize insensitive organisms and to indicate whether the patient's blood is bacteriostatic.

Blood Counts and Sedimentation Rate. At first the sedimentation rate was estimated using a Wintrobe tube; later the reading was corrected by the method of Wintrobe and Landsberg (1935). The uncorrected rate was invariably raised before treatment but, of 13 cases in which a correction from the hæmatocrit reading was applied, 1 was within normal limits and 2 were high normals (12 and $14 \mathrm{~mm}$. in the first hour).

In 24, the hæmoglobin on the Haldane standard was less than 70 per cent on admission and less than 50 per cent in 8 cases. On admission an increase in the number of polymorphonuclear leucocytes was found in 26; this was not always revealed by a total leucocyte count, which was increased in only 14 cases.

Cardiac and Renal Investigations. There were 28 patients who were fit for $6 \mathrm{ft}$. teleradiograms before treatment; in 8 the heart was not appreciably enlarged, in 13 the cardiothoracic ratio was between 1.9 and 1.6 , and in 7 gross enlargement was present (cardiothoracic ratio 1.5 or less).

Cardiograms were taken before treatment in 32 cases; 13 were within normal limits, including 6 with left axis deviation and aortic incompetence. The principal abnormalities were prolonged $\mathbf{P}-\mathbf{R}$ in 1, right axis deviation in 2, left ventricular strain in 9, low voltage QRS (all leads) in 2, low voltage $\mathrm{T}$ (all leads) in 5, right B.B.Bl. in 1, and dextrocardia in 1 case (more than one abnormality were present in 2 cases). The infrequency of right axis deviation is further confirmation of the absence of severe mitral lesions in these cases.

We have accepted as abnormal a blood urea of more than $40 \mathrm{mg}$. per $100 \mathrm{c.c}$. and a standard urea clearance of less than 70 per cent. When the urinary deposit contained a few red cells with, usually, a few leucocytes and granular and cellular casts, we have classified the abnormality as "slight," whereas when many red cells were visible as a naked-eye deposit, usually accompanied by many leucocytes and casts, we have described the abnormality as "gross." By these criteria, the renal function was impaired in 10 cases, whereas the urinary deposit was always abnormal, the changes being " slight" in 19 and " gross" in 14 cases.

\section{TREATMENT}

Apart from the treatment of heart failure, of anæmia, and of focal sepsis, the only therapeutic measure used in these cases was the administration of penicillin.

At first various schemes were adopted to determine the duration of treatment and the dosage of penicillin necessary to control the infection; these experiments were conducted at all centres and the results have been summarized by Christie (1946). The most satisfactory course for initial treatment was 0.5 mega unit daily for 28 days. Since relapses in some of 
the earlier cases were subsequently treated by a full course, and because the 28-day course was adopted very early at this centre, it happens that, of 25 of our cases who lived to complete treatment, only 3 did not receive the full course of 0.5 mega unit (or more) daily for 28 days. Of these 3, one was the first in this series and died before we adopted the longer course; one, who remains well, refused treatment after two courses of nine and ten days, and in one treatment had to be stopped after three weeks owing to severe thrombopenia; this patient died four weeks later from heart failure with her infection apparently controlled. Treatment known to be inadequate does not, therefore, play an important part in assessing the results in these cases.

Penicillin is remarkably free from undesirable toxic effects but, in this series, the need to give large doses for several weeks afforded a useful opportunity to study such effects. In the earlier cases we noticed that, although the temperature rapidly became normal after starting treatment, it often rose again at the beginning of the second week and an intermittent pyrexia persisted until penicillin therapy ended (Fig. 1, Case 24). During the fourth week of therapy

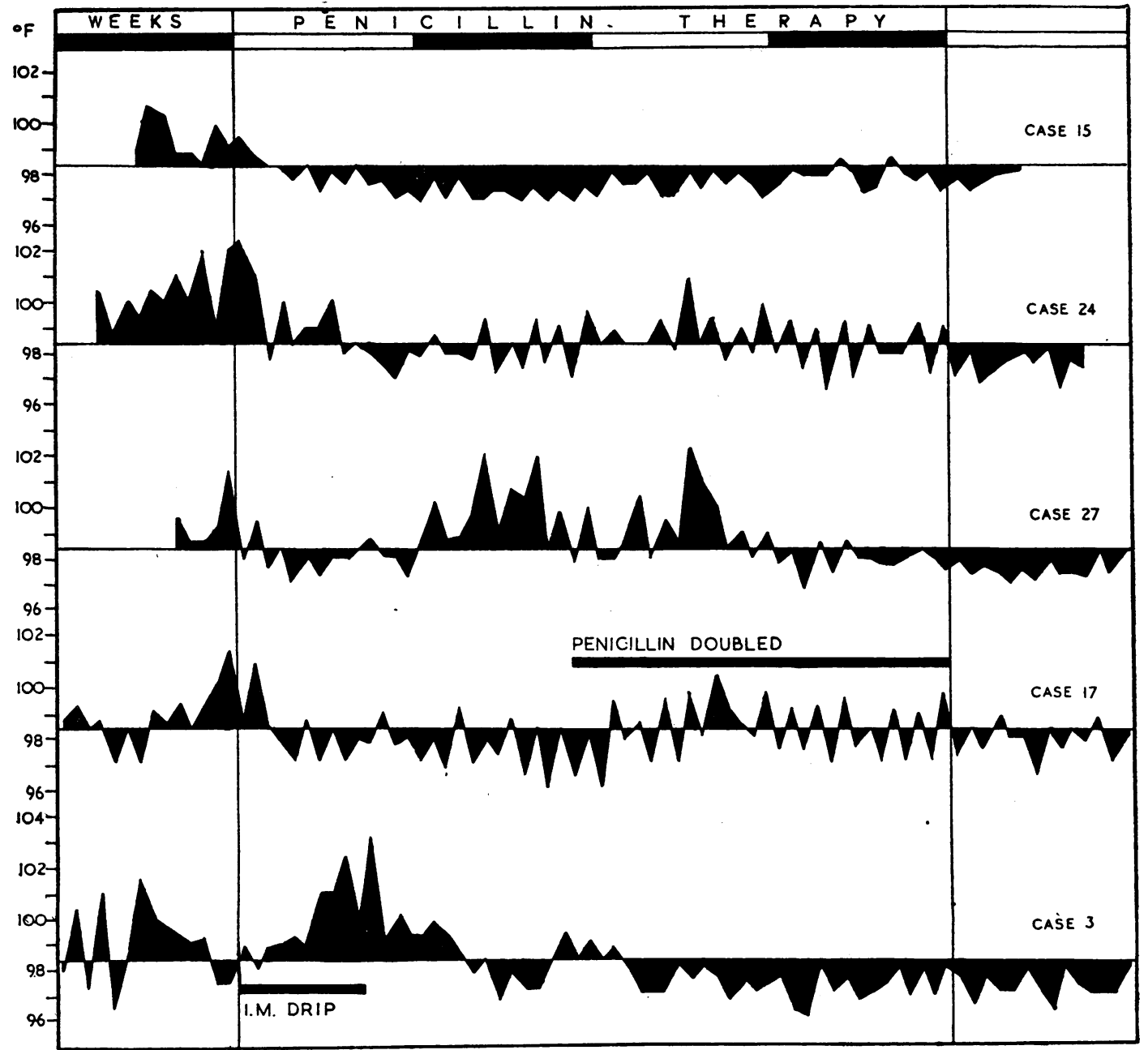

FIG. 1.-Temperature Charts during Treatment. Case 15. Uncomplicated response-apyrexial after first two days. Cases 24, 27, and 17. Penicillin pyrexia. Case 3. Pyrexia due to intramuscular drip, settling when method of administration changed to three-hourly injections. 
the pyrexia tended to diminish and sometimes disappeared (Fig. 1, Case 27). At first we were inclined to suspect that such pyrexia was due to failure to control the infection and this led us to double the dose of penicillin in 3 cases, but the pyrexia then became more striking (Fig. 1, Case 17). Pyrexia of this type was noticed in 13 cases and in every case it disappeared when penicillin was discontinued. We conclude that when the temperature falls to normal in the first week, a subsequent rise in the second week, which either persists until penicillin is stopped or disappears during the fourth week of treatment, can be regarded as a drug fever. More highly purified penicillin became available later but this did not reduce the incidence of penicillin pyrexia which developed in 5 of the first 17 and in 8 of the last 16 cases. We are, therefore, inclined to attribute the pyrexia to penicillin itself and not to impurities. Penicillin pyrexia is of no prognostic significance, for of these 13 cases only 3 died. Recurrence of pyrexia during treatment has been previously recorded by Dawson and Hobby (1944), Anderson and Keefer (1945), Bloomfield and Halpern (1945), Meads et al. (1945), and Bloomfield et al. (1945); it has usually been attributed to emboli, infection by injections or drips, or to absorption of healing lesions, but Dawson and Hobby (1944) and Bloomfield and Halpern (1945) considered it might be due to penicillin or an associated impurity. It is agreed that pyrexia during treatment does not necessarily indicate failure to control the infection.

In 2 cases an urticarial rash developed during the third week of treatment and disappeared a few days after the end of treatment. Urticarial rashes have been previously described by Keefer et al. (1943), Bloomfield et al. (1945), Mokotoff et al. (1946), and Geiger and Goerner (1946). In one case bruising in several parts of the body was noticed on the fourteenth day of treatment and the platelet count was 50,000 per c.mm.; a week later the count had fallen to 35,000 , and it seemed best to stop treatment; the count then increased slowly to 58,000 before death four weeks later. In another case the platelet count was 95,000 before death on the twentieth day of treatment.

We have usually given penicillin by three-hourly intramuscular injection and this has been well tolerated for long periods; only one patient refused to continue treatment for the prescribed time. In 5 cases, however, we used a continuous intramuscular drip, changing the site every 24 hours; but in each case, after a few days, we were obliged to change to threehourly injections owing to severe pain at the site of injection and the development of pyrexia (Fig. 1, Case 3). In all these cases the penicillin was of the less purified type and we have not tested this method using the more highly purified preparations now available.

TABLE V

Average Penicillin Serum Levels with 0.5 Mega Unit Daily

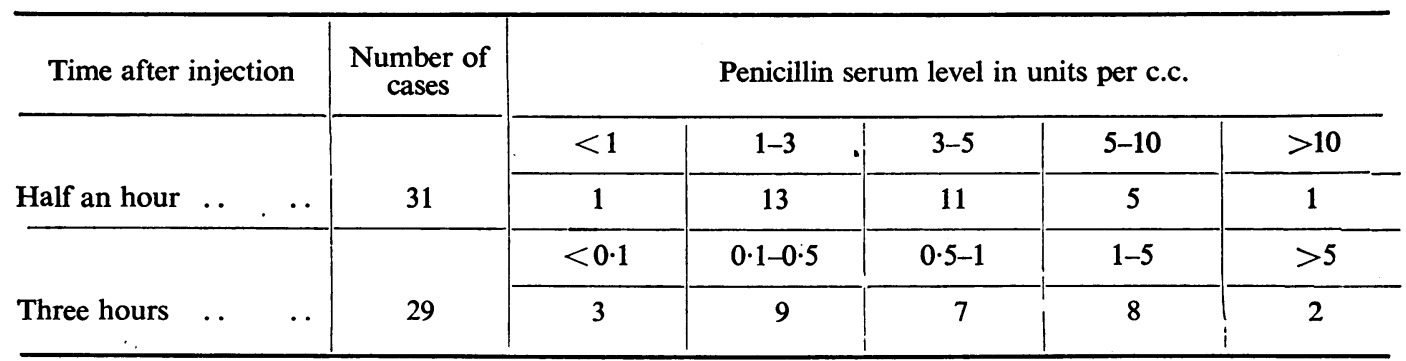

Penicillin serum levels were estimated half an hour and three hours after the injection. All our patients received 0.5 mega unit daily and the figures given in Table $\mathrm{V}$ are averages of the levels reached with that dose. In 2 with severe renal failure, penicillin retention led to threehour serum levels of 12 and 8 units per c.c. ; a similar observation was made by Sanderson and McEntegart (1946). We have not been able to correlate the penicillin level with the outcome 
of treatment but the levels attained appear to be bacteriostatic for all except the most insensitive organisms (Table V).

Dental and Tonsillar Infection. On admission tonsillar sepsis was present in 4 cases; 2 of these died and in the other 2 tonsillectomy was undertaken during convalescence, 0.5 mega unit of penicillin being given daily for two days before and three days after operation. On admission there was clinical or radiographic evidence of paradontal infection in 9 cases; in 4 of these treatment was undertaken during the third or fourth weeks of penicillin therapy and in 4 with penicillin cover during convalescence ; 1 patient refused dental treatment. In all 10 cases in which focal sepsis was treated under penicillin cover there was no post-operative pyrexia and blood cultures remained sterile. We now prefer to eradicate focal sepsis during penicillin treatment of the bacterial endocarditis, for reinfection is possible if septic foci are still present when penicillin is discontinued.

\section{Results of TREATMENT}

Of 33 patients treated, 15 have died and 18 are alive and free from signs of infection: 9 for 6 to 12 months after the completion of treatment, 7 for 12 to 18 months, and 2 for over 18 months. In discussing these results in detail it is convenient to consider separately the successful and the unsuccessful cases for different problems have been investigated in each group; in successful cases we have been interested principally in studying the response to treatment and the degree of recovery which has been achieved, whereas, in those unsuccessful cases in which death occurred from heart failure, uræmia, or vascular accidents, despite control of the infection by penicillin, we have had an opportunity of investigating the factors that prevented recovery and of assessing the extent to which healing had progressed during the interval of up to three months between arrest of the infection and death.

\section{SUCCESSFUl CASES}

The events during treatment in a typical successful case are illustrated in Fig. 2. The temperature fell to normal within a few days of beginning treatment but the pulse settled much less rapidly; usually the rate remained somewhat rapid for two to four weeks. In the case illustrated the patient was confined to bed for three weeks after the end of treatment although the temperature and pulse rate were normal; carefully graduated and cautiously applied bed exercises were then started but were followed by an immediate rise in the pulse rate and, when the patient was allowed up for a few minutes ten days later, the pulse rate increased to $116 \mathrm{a}$ minute taking several weeks to return to normal. In this case the history of infection was comparatively short and the general condition of the patient good, but it is clear that the heart had been considerably damaged by the infection. Great care is necessary during the period of increasing activity following successful treatment, however well the patient may appear when resting in bed; similar opinions were expressed by Anderson and Keefer (1945) and Meads, Harris, and Finland (1945).

The first blood culture after beginning penicillin was made between the first and seventh days of treatment and was sterile in 16 of our 18 successful cases; in the remaining 2 blood cultures were positive on the second day but sterile on the ninth day of treatment. In successful cases, once the blood was rendered sterile, subsequent cultures were always negative during treatment, but 3 patients, who ultimately recovered, relapsed after the initial course of penicillin had been completed.

In 4 successful cases cardiograms before treatment showed very low voltage $T$ waves in all the limb leads but subsequently returned to normal (Fig. 7). T wave changes associated with heart failure were noted by Bloomfield et al. (1945), but heart failure did not occur in our 4 cases. 
During and after treatment the sedimentation rate fell slowly and, in our successful cases, reached normal in an average of five weeks after the completion of treatment.

There was often little rise in hæmoglobin during treatment but subsequently steady improvement took place and a normal level was attained, without transfusion, about three months after the end of treatment (Fig. 3). Transfusion was necessary in only two successful cases and is to be avoided if possible owing to its dangers when heart failure is present.

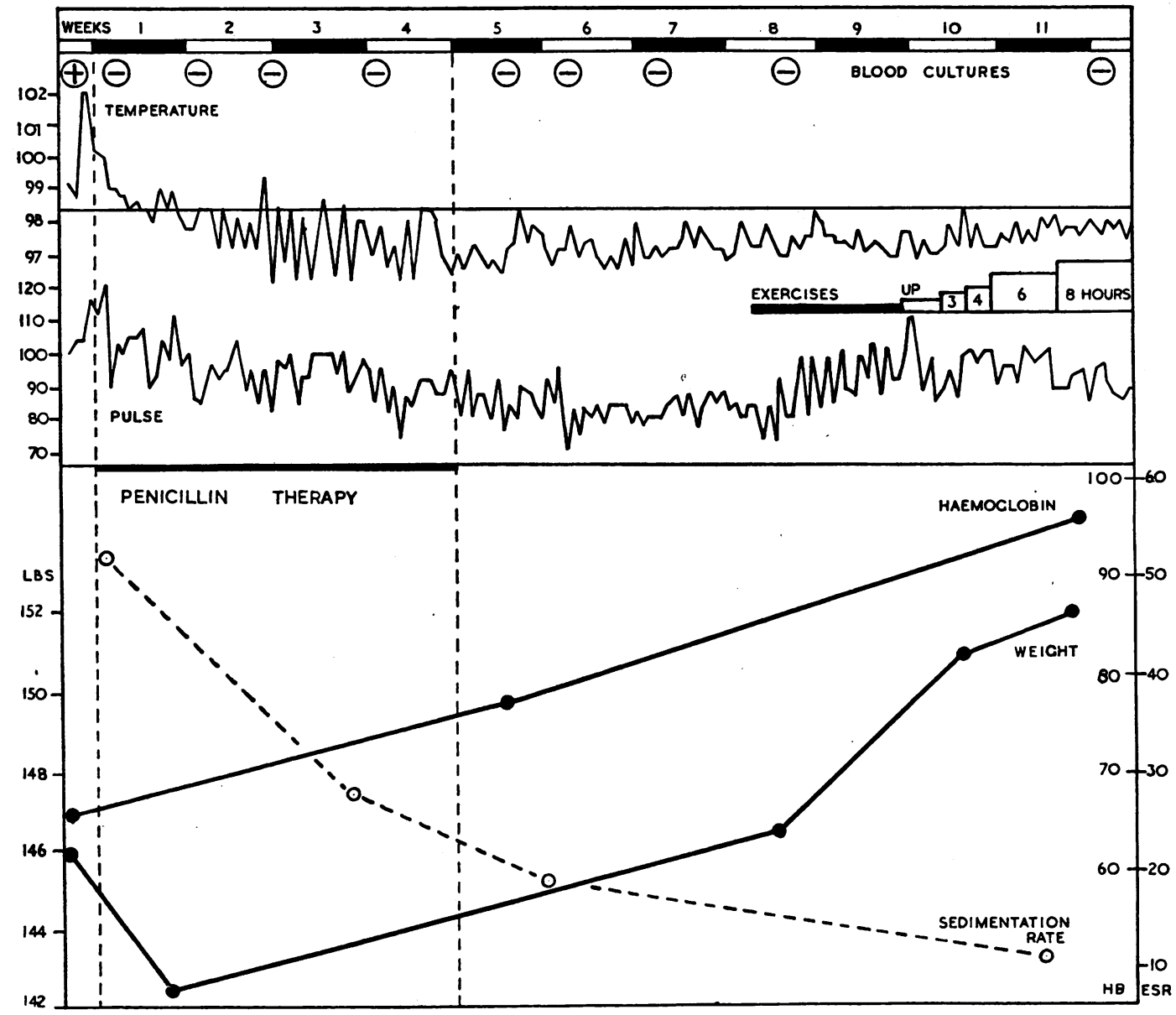

FIG. 2.-Chart showing response to treatment in typical successful case. Case 13. The slow fall in pulse rate during treatment and the increase in rate on commencing activity are notable features.

Gain in weight continued for up to nine months after treatment and in eight of the successful cases the gain averaged $23 \mathrm{lb}$.

The convalescence of these patients was, therefore, slow and, owing to the cardiac damage, required careful management. The average period in hospital was fourteen weeks in our successful cases; full activity was rarely resumed sooner than six months after the end of treatment.

\section{Degree of Recovery}

A severe infection of the myocardium and valves leading to tissue destruction and fibrosis, present for periods up to six months before arrest by penicillin, is likely to leave behind it 
further cardiac damage. We have tried to assess the frequency and severity of this damage in three ways: (1) by comparing the patients' capacity for effort and ability to follow their occupation before infection and after recovery, (2) by reviewing the radioscopic changes in the size and shape of the heart and the changes in the cardiogram during the recovery stage, and (3) by searching for physical signs indicating new valvular lesions or increase in the severity of established lesions.

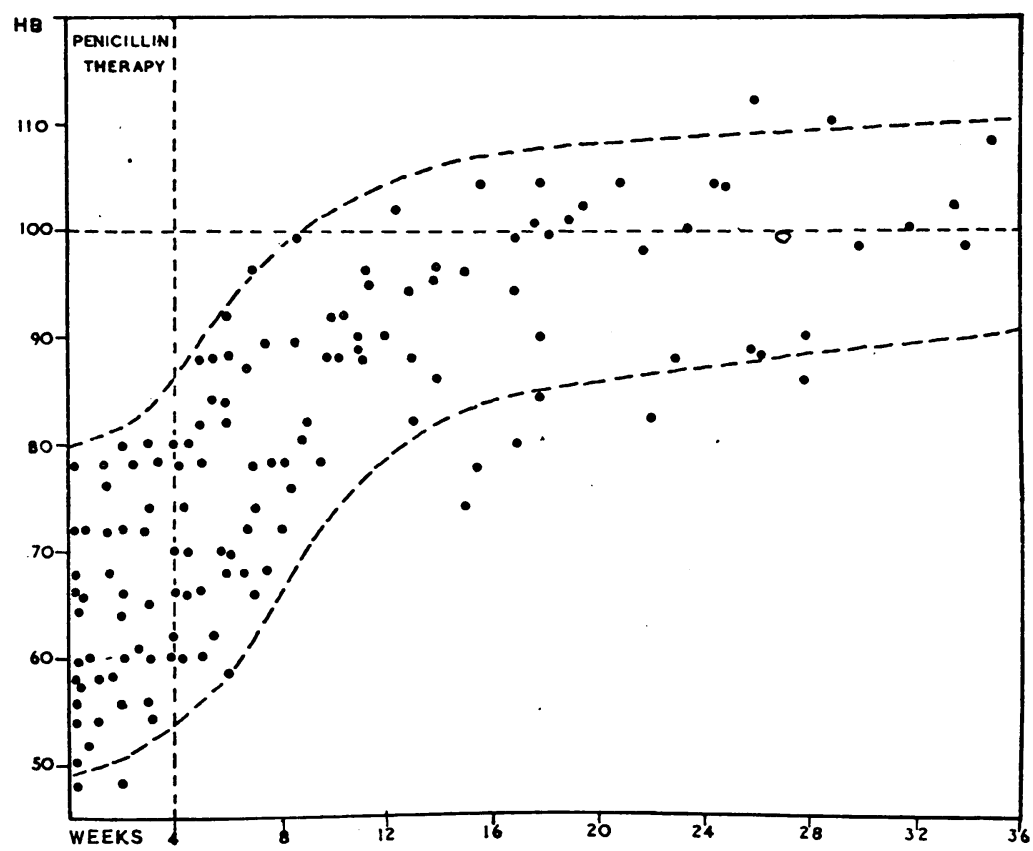

FIG. 3.-Scatter graph showing rise in hæmoglobin without transfusion in 12 successful cases with an initial hæmoglobin below 80 per cent.

The previous occupations of 18 recovering patients and the number who have, so far, returned to work are enumerated in Table VI. Of our 18 patients, 12 are back at their old work and all say that they notice no change in their capacity for exertion. One of these, who gave up her work as a machinist on marriage, has resumed her employment although she now has a young child born during the infection. Following that confinement she was given a ten-day course of treatment, but subsequently relapsed and, during her second course of penicillin, developed a coronary embolus with cardiographic changes indicating posterior infarction.

TABLE VI

Return to Work of 18 Recovering Patients

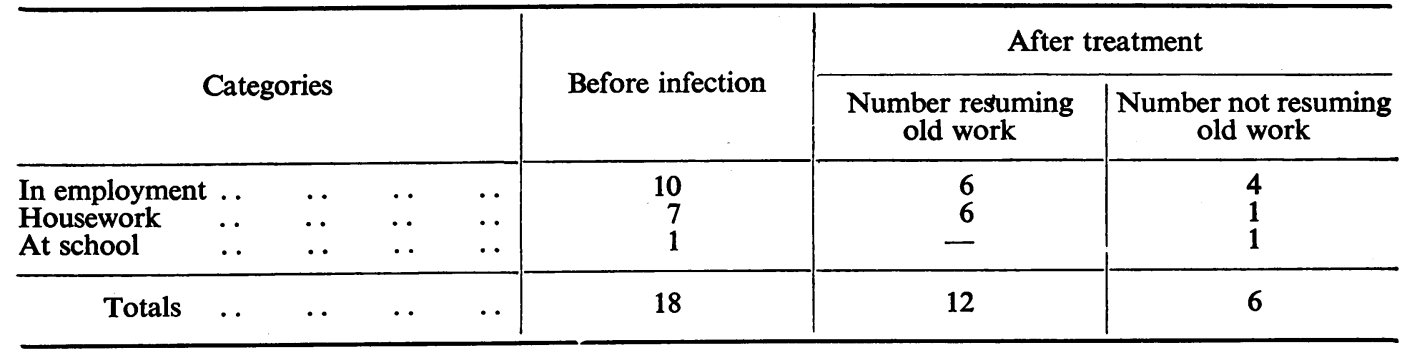


One of the 6 patients who have not resumed work is still convalescent (33), one is fit for work and maintains that he is as well as before his illness but he has a specialized occupation and has not yet found suitable work. One patient had considerable restriction of her capacity for effort (Class III) before the infection; she seems no worse now but has been advised not to resume work as there is no economic necessity for her to do so. Three patients have subjectively deteriorated $(10,17,22)$, and are unfit for work.

The degree of recovery in these cases is surprisingly good; unfortunately, subjective estimation of fitness by the patient is open to error and objective methods reveal another aspect of the picture.

Teleradiograms and Cardiograms. It is difficult to obtain strictly comparable teleradiograms for the serial measurement of heart size; we have, therefore, disregarded small changes in the cardiothoracic ratio that could be explained by a difference in position of the chest or diaphragm and have confined our attention to undoubted alterations in size.

In untreated-subacute bacterial endocarditis the size of the heart increases progressively as the disease advances for, in 6 of our cases, comparison of teleradiograms taken earlier in the illness with those before treatment showed that in each case the heart had increased in size, sometimes considerably (Fig. 4). After treatment there was no further increase in heart size in 13 of the 16 successful cases in which we have adequate serial teleradiograms. This suggests that, as we should expect, cardiac damage due to the infection does not often increase after successful treatment. But we have little evidence to indicate that the enlargement which occurs during the infection diminishes appreciably after apparent cure of the disease; in 9 of our 13 cases the heart size has remained unchanged for periods between six and eighteen months after treatment, and in only 4 cases has there been any suggestion of a decrease in size. In 1 of these 4, this decrease followed ligation of a patent ductus (Case 33) and is, therefore, irrelevant to this discussion; in the other 3 we are not convinced that the alteration is sufficient to be significant. Our observations, therefore, indicate that after successful treatment the progressive cardiac enlargement of the untreated disease usually stops, but enlargement that has already taken place is generally irreversible.

In 3 patients cardiac enlargement continued after treatment; all these are less fit than before the infection. Case 10 is interesting for she first came under our observation when pregnant, four weeks before the first symptom of infection. She then had a loud aortic diastolic murmur, maximal to the left of the sternum and audible at the apex, with a soft systolic murmur maximal at the apex but no clear evidence of a mitral lesion. The blood pressure was 150/45. The infection was treated six weeks after the first symptom appeared and the physical signs remained unchanged. A year later a rough aortic systolic murmur and thrill appeared, but the aortic lesion remained predominantly regurgitant for the blood pressure was $135 / 35$. Three months later a rumbling mitral diastolic murmur was heard for the first time and cardioscopy revealed increased prominence of the pulmonary conus (Fig. 5) but, although the change in the valvular lesions is clinically obvious, the cardiac silhouette is not yet grossly modified and there is no significant alteration in the cardiogram. The other two cases form a striking contrast for, although the physical signs have altered much less, the heart has considerably enlarged since treatment and serial cardiograms have shown significant changes. In Case 22 the progressive increase is illustrated in Fig. 6 and the development of right axis deviation in Fig. 7 (A and B). No diastolic murmur has been heard at any stage, but the apical systolic murmur is now louder. In Case 17 progressive cardiac enlargement followed the completion of treatment (Fig. 8) and comparison of the cardiogram taken before treatment with that a year later showed that, in addition to recovery of the $T$ waves previously noted, the $\mathbf{P}$ waves had changed and the electrical axis had shifted towards the right (Fig. 7). Although the radiograms are typical of advanced mitral stenosis there has never been a diastolic or presystolic murmur, but the apical systolic murmur has become much louder. In these 


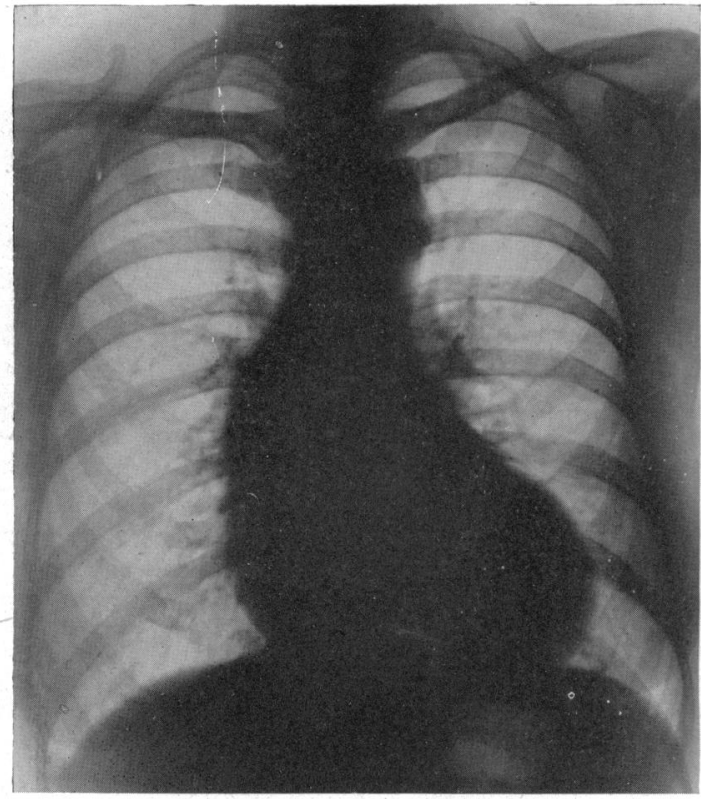

A

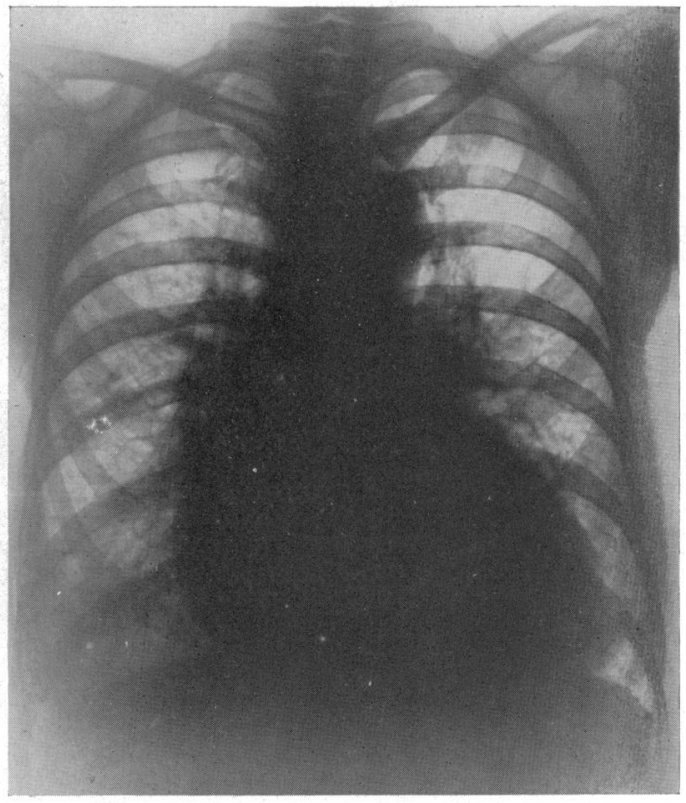

B

FIG. 4.-Teleradiograms showing cardiac enlargement in untreated subacute bacterial endocarditis. Case 8. (A) Six weeks before treatment. (B) Three days before treatment. A considerable change has occurred in a few weeks.

two cases it is difficult to account for the enlargement of the right ventricle and the changes in axis deviation except by the development of increased mitral stenosis.

These three cases suggest the possibility that stenotic valvular lesions may occasionally develop or increase after successful treatment with penicillin; this is not unlikely since repair

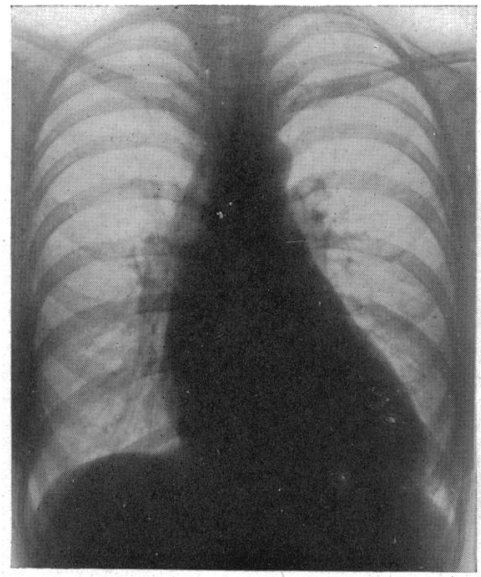

A

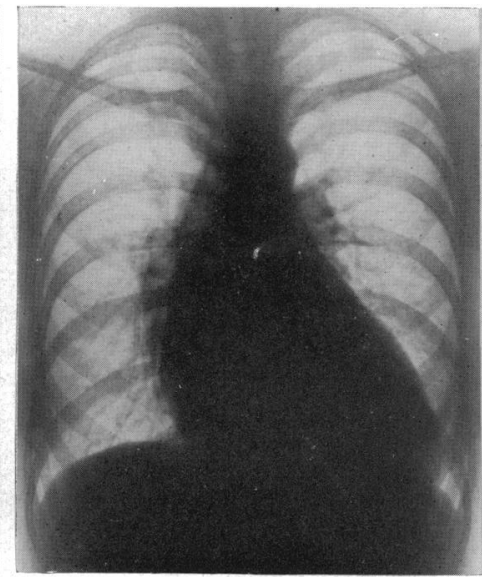

B

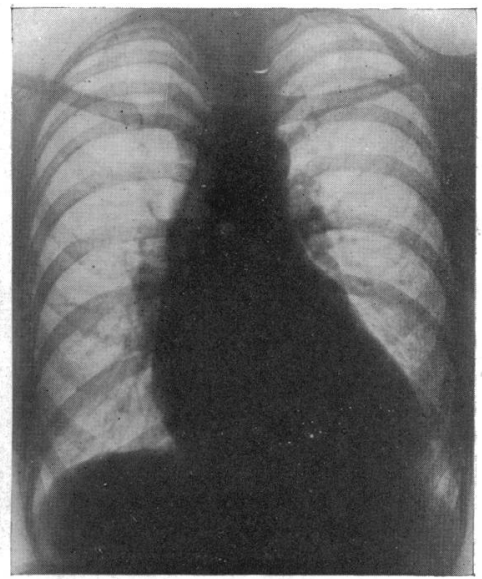

C

Fig. 5.-Teleradiograms. Case 10. (A) Before treatment. (B) Twelve months after treatment (C) Seventeen months after treatment, showing slight prominence of pulmonary conus. 


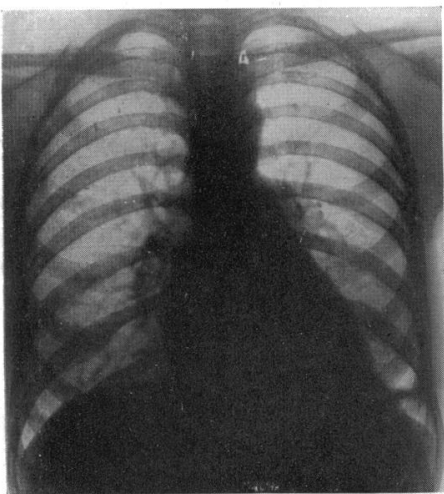

A

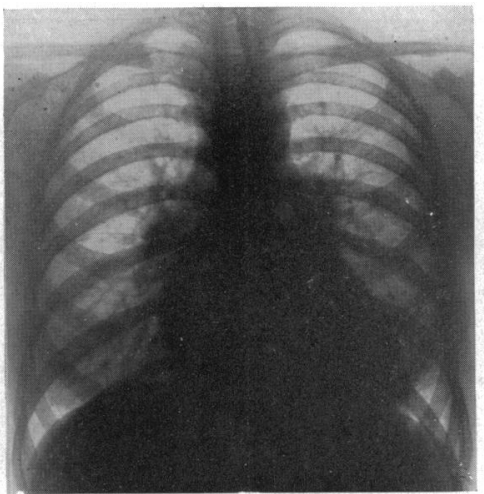

B

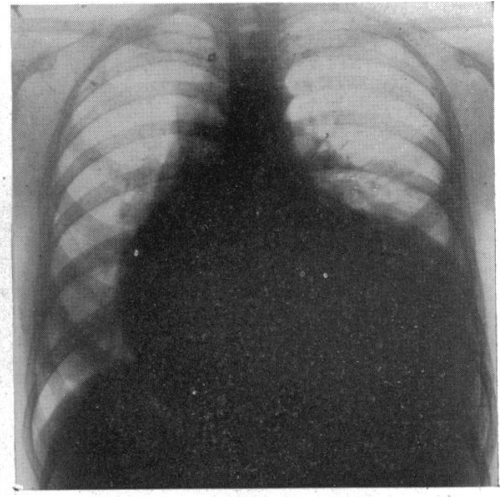

C

FIG. 6.-Teleradiograms showing progressive cardiac enlargement after contro of infection. Case 22 (A) Before treatment. (B) Two months after treatment. (C) Nine months after treatment, showing gross enlargement. (See cardiograms, Fig. 7.)

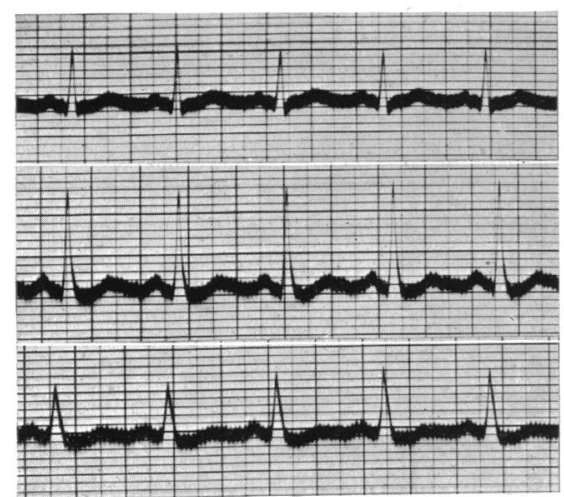

A

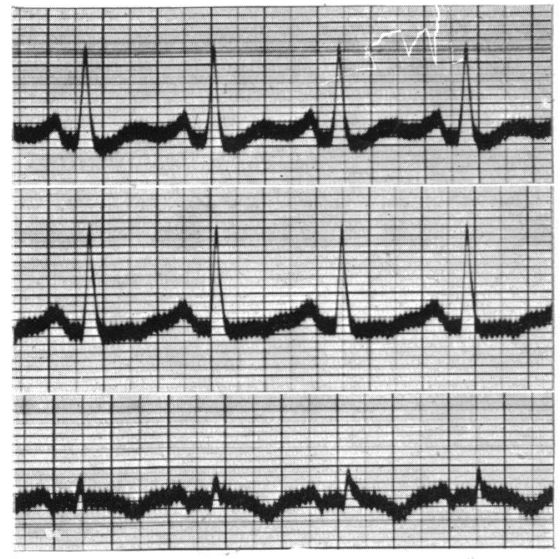

C

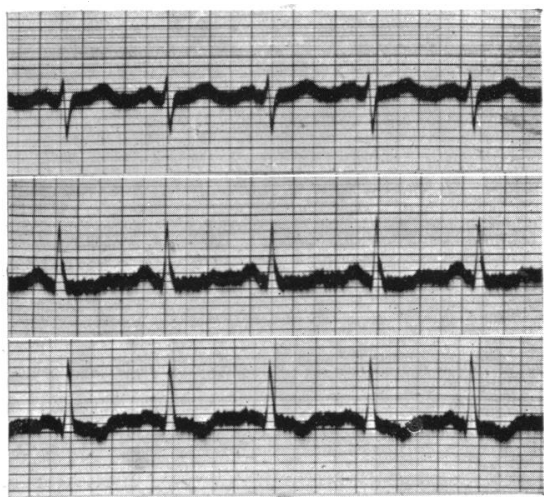

B

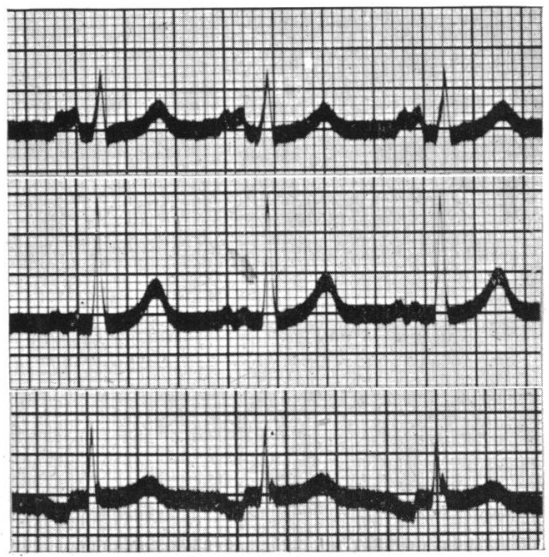

D

Fig. 7.-Cardiograms. (A) Case 22, during treatment. (B) Case 22, three months after treatment, showing development of right axis deviation. (C) Case 17, during treatment. (D) Case 17, one year after treatment, showing recovery of $T$ waves, change in form of $P$ waves and increase in voltage of $Q R S$ III with decrease in voltage of QRS I, indicating a shift of the electrical axis towards the right. (Reduced. to four-fifths.) 
of the valvular damage is accompanied by fibrosis. If the infection largely destroys the valve, a stenotic lesion is most unlikely to develop during healing; it is the less damaged valve which will be liable to this complication. We cannot, of course, be sure that the changes are not due to the spontaneous progress of the rheumatic lesions but it is doubtful if this explanation is adequate.

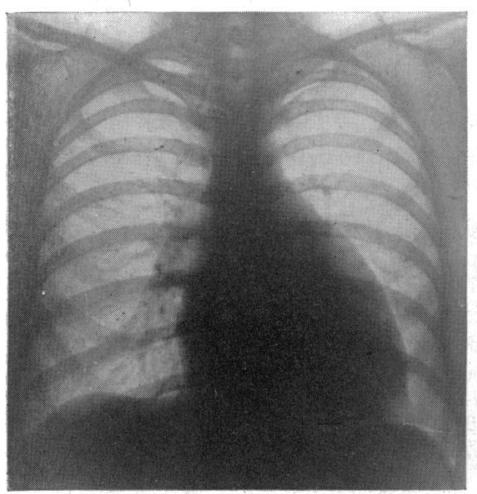

A

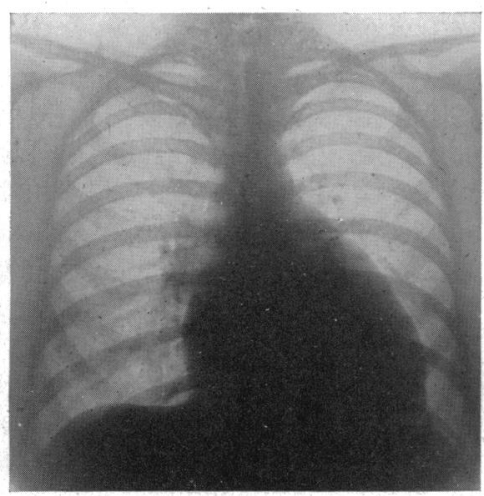

B

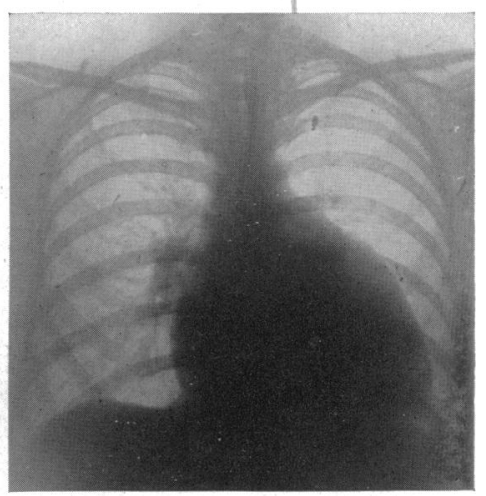

C

FIG. 8.-Teleradiograms showing progressive cardiac enlargement after control of infection. Case 17. (A) Three days after treatment. (B) Four months after treatment. (C) Ten months after treatment. (See cardiograms, Fig. 7.)

\section{Relapses}

In 5 cases short courses of penicillin had been given before admission; a positive blood culture was subsequently obtained in all. In 3 the relapse occurred within two weeks and in the others at some unknown period within five weeks and four months respectively. It appears that when the relapse was promptly detected and adequate treatment instituted, recovery followed, but, in both cases in which there was delay in detecting the relapse the patient died.

\section{TABLE VII}

Relapses Following Initial Course After Admission

\begin{tabular}{c|c|c|c|c}
\hline Case & Course & $\begin{array}{c}\text { Time of relapse } \\
\text { after end of } \\
\text { course }\end{array}$ & $\begin{array}{c}\text { Subsequent } \\
\text { treatment }\end{array}$ & Result \\
\hline 1 & $1 \times 5$ & $0-5$ days & $\frac{1}{4} \times 18$ & Died \\
2 & $1 \times 10$ & $9-13$ weeks & $\frac{1}{2} \times 28$ \\
3 & $\frac{1}{2} \times 10$ & $0-9$ days* & $\frac{1}{2} \times 28$ & Well \\
1 & $\frac{1}{2} \times 10$ & $0-6$ days & $\frac{1}{2} \times 9$ \\
$\frac{1}{2} \times 22$ & Well & Died \\
\hline
\end{tabular}

* No culture, recurrence of pyrexia.

$\uparrow$ Insensitive organism, died during second course.

In 5 cases a relapse followed the initial course after admission (Table VII) in 3 cases within a week of the end of treatment, and in 1 case three weeks after treatment. The remaining case is interesting; thirteen weeks after a short course of treatment a positive culture was obtained although the patient was free from symptoms and there were no clinical signs of infection. Regular blood cultures are, therefore, necessary during convalescence for early detection of relapses which may not, at first, show much clinical deterioration. Two patients 
whose infection relapsed following inadequate treatment after admission ultimately died, one was infected with an insensitive organism and the other, our first case, never had a full course of penicillin.

Relapses following inadequate treatment, if promptly detected and adequately re-treated, do not appear to have prejudiced the ultimate outcome in these cases. In their case Florey and Florey (1944) found a four-fold increase in the resistance of the organism after treatment; they attributed this to penicillin therapy. Bloomfield and Halpern (1945) also found one case in which an organism, sensitive before treatment, became insensitive after treatment, and Christie (1946) considers that, in assessing the danger of inadequate treatment, this possibility ought not to be ignored. In one of our cases, in which the blood culture remained positive during treatment, the resistance of the organism increased from 4 to 18 times that of the Oxford staphylococcus. On the other hand, Meads et al. (1945), Anderson and Keefer (1945), and Dawson and Hunter (1946) were unable to find any change in the resistance of the causative organisms in their cases. Since the measurement of resistance is open to criticism, the response to re-treatment may be a more reliable test; there is at present no evidence to suggest that if patients infected with an initially sensitive organism relapse after inadequate therapy, they will often fail to respond to a subsequent full course. Relapse after prolonged treatment may carry a graver prognosis as Christie (1946) has suggested. No patient in this series. relapsed after a 28-day course but, from our subsequent experience, we know this can happen even if the organism is sensitive.

\section{UnSUCCESSFul CASES}

It is essential to know how often death is due to failure to control the infection. We have studied this problem in three ways: (1) by clinical assessment of the control of infection, (2) by histological assessment of the degree of healing, and (3) by post-mortem culture of the vegetations.

Clinical Criteria of Control of Infection. In successful cases the blood culture became negative and the temperature fell to normal by the end of the first week. Recurrence of pyrexia in the second week was not regarded as significant if the blood culture remained sterile. Usually there was little rise in hæmoglobin or gain in weight during treatment. After successful penicillin treatment the weekly blood culture remained sterile and the temperature was normal unless another infection was present or major infarction took place; the hæmoglobin and weight increased steadily.

Histological Criteria of Healing. In untreated subacute bacterial endocarditis the vegetation consists essentially of a thrombus lying on a valve and covered, wholly or in part, by a layer of organisms. Organization is present, for fibroblasts and capillaries grow into the thrombus from the valve and are associated with large mononuclear cells. Polymorphs, and frequently lymphocytes, indicate active inflammation at the base of the vegetation and in the adjacent valve.

After penicillin therapy the first sign of healing was the disappearance of the active inflammatory lesion; removal of the hyaline thrombus by mononuclear cells then began and foreign-body giant cells appeared in the zone of bacteria. Although organisms were still present at this stage, they stained less readily and were presumably dead since cultures from the vegetation remained sterile. Finally, in the most advanced stage of healing that was seen, the thrombus was very small, often consisting of a little hyaline material lying on scanty fibrous tissue but sometimes calcified, when rather more fibrous tissue was found.

The degree of healing was assessed solely on histological grounds, without reference to clinical evidence of control of infection or period of survival after the completion of treatment. The vegetations were classified, according to the degree of healing, into three stages (Table VIII). 
TABLE VIII

Histological Criteria of Healing

Stage 1.-Indistinguishable from vegetations of untreated case-active inflammation.

Stage 2.-Much organization, no inflammatory reaction (or only slight): intermediate between Stages 1 and 3.

Stage 3.-Organization advanced, probably nearly healed.

\begin{tabular}{|c|c|c|c|}
\hline Feature & Stage 1 & Stage 2 & Stage 3 \\
\hline 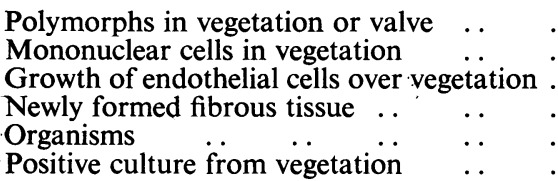 & $\begin{array}{l}\text { Moderate number } \\
\text { Some } \\
\text { Never } \\
\text { Little } \\
\text { Yes } \\
\text { Sometimes }\end{array}$ & $\begin{array}{l}\text { Few or none } \\
\text { Some } \\
\text { Never } \\
\text { Much (cellular) } \\
\text { Yes } \\
\text { Never }\end{array}$ & $\begin{array}{l}\text { None } \\
\text { Few or none } \\
\text { Often } \\
\text { Variable amount } \\
\text { Sometimes } \\
\text { Never }\end{array}$ \\
\hline
\end{tabular}

In untreated bacterial endocarditis, although acute inflammatory changes are always present in some part of the lesion, there may also be areas of healing; in assessing healing in these cases it was, therefore, necessary to examine several sections from each vegetation and to form an opinion from the composite picture. A general impression of the process of healing after penicillin therapy can be gained from the naked-eye appearances and these are illustrated in Fig. 9.

Post-mortem Culture of Vegetations. Before removal of the heart all the great vessels were tied; the heart was then removed intact. With aseptic precautions the ventricular wall

TABLE IX

Control of Infection and Degree of Healing in 15 fatal Cases

\begin{tabular}{|c|c|c|c|c|c|c|c|}
\hline Case & $\begin{array}{l}\text { Time of } \\
\text { death }\end{array}$ & $\begin{array}{l}\text { Duration of } \\
\text { normal } \\
\text { temperature } \\
\text { before death }\end{array}$ & $\begin{array}{c}\text { Duration of } \\
\text { sterile blood } \\
\text { culture } \\
\text { before death }\end{array}$ & $\begin{array}{l}\text { Anatomical } \\
\text { condition of } \\
\text { vegetations * }\end{array}$ & $\begin{array}{c}\text { Post- } \\
\text { mortem } \\
\text { culture of } \\
\text { vegetations }\end{array}$ & $\begin{array}{c}\text { Control } \\
\text { of } \\
\text { infection }\end{array}$ & $\begin{array}{l}\text { Degree } \\
\text { of } \\
\text { healing }\end{array}$ \\
\hline $\begin{array}{r}5 \\
20\end{array}$ & $\begin{array}{l}\text { During } \\
\text { treatment } \\
\text { 6th day }\end{array}$ & 2 days & $\overline{d a x}$ & $\Rightarrow-1$ & - & $?$ & - \\
\hline 20 & 6th day & 3 days & 2 days & Stage 1 & $\begin{array}{l}\text { Strept. } \\
\text { viridans }\end{array}$ & 0 & 0 \\
\hline $\begin{array}{r}9 \\
12\end{array}$ & $\begin{array}{l}\text { 15th day } \\
20 \text { th day }\end{array}$ & $\begin{array}{c}\text { nil } \\
7 \text { days }\end{array}$ & $\begin{array}{l}\text { nil } \\
5 \text { days }\end{array}$ & $\begin{array}{c}\text { (a) Stage } 1 ;(b) \text { Stage } 2 \\
\text { Stage } 1\end{array}$ & $\overline{\text { Sterile }}$ & $\begin{array}{l}0 \\
?\end{array}$ & $\frac{ \pm}{0}$ \\
\hline 25 & $\begin{array}{l}20 \text { th day } \\
27 \text { th day }\end{array}$ & 5 days $\ddagger$ & 14 days & $\begin{array}{l}\text { Stage } 1 \\
\text { Stage } 1\end{array}$ & Sterile & + & $\begin{array}{l}0 \\
0\end{array}$ \\
\hline 30 & 27 th day & 24 days & 24 days & (a) and (b) Stage 1 & $\begin{array}{l}\text { only§ } \\
\text { Sterile }\end{array}$ & & 0 \\
\hline & $\begin{array}{c}\text { After } \\
\text { treatment }\end{array}$ & & & & & & \\
\hline $\begin{array}{r}28 \\
8\end{array}$ & $\begin{array}{l}4 \text { days } \\
4 \text { weeks }\end{array}$ & $\begin{array}{l}10 \text { days } \ddagger \\
7 \text { weeks }\end{array}$ & $\begin{array}{l}26 \text { days } \\
8 \text { weeks }\end{array}$ & $(a)$ and $(b)$ Stage 2 & Sterile & $\begin{array}{l}+ \\
+\end{array}$ & + \\
\hline 29 & 4 weeks & & 8 weeks & Stage 2 & Sterile & + & + \\
\hline 1 & 6 weeks & nilø & 8 weeks & (a) Stage 2; (b) Stage 3 & Sterile & + & ++ \\
\hline 14 & $\begin{array}{l}10 \text { weeks } \\
10 \text { weeks }\end{array}$ & 13 weeks & 13 weeks & Stage 2 & Sterile & + & \pm \\
\hline 20 & 13 weeks & $\begin{array}{l}10 \text { weeks } \ddagger \\
16 \text { weeks }\end{array}$ & $\begin{array}{l}13 \text { weeks } \\
17 \text { weeks }\end{array}$ & Stage $2 ; \overline{(a)}$ and $(b)$ & 二 & + & ++ \\
\hline $7+2>0$ & 13 weeks & 16 weeks & 17 weeks & (a) and (b) Stage 3 & - & + & +++ \\
\hline
\end{tabular}

* When more than one valve was affected the degree of healing is stated in both.

$\dagger$ Two courses of treatment.

† Penicillin pyrexia.

$\$$ B. coli septicæmia during life.

B. coli urinary infection.

I Multiple pulmonary emboli after treatment. 
was incised, portions of the vegetations removed, ground up in a sterile mortar, and inoculated on to blood agar plates and into Hartley broth.

The observations made in these three ways in 15 fatal cases are summarized in Table IX. In Cases 5 and 20, death occurred too soon after beginning treatment to estimate the full effect of penicillin but the temperature had been rapidly controlled in both. In Case 20, however,

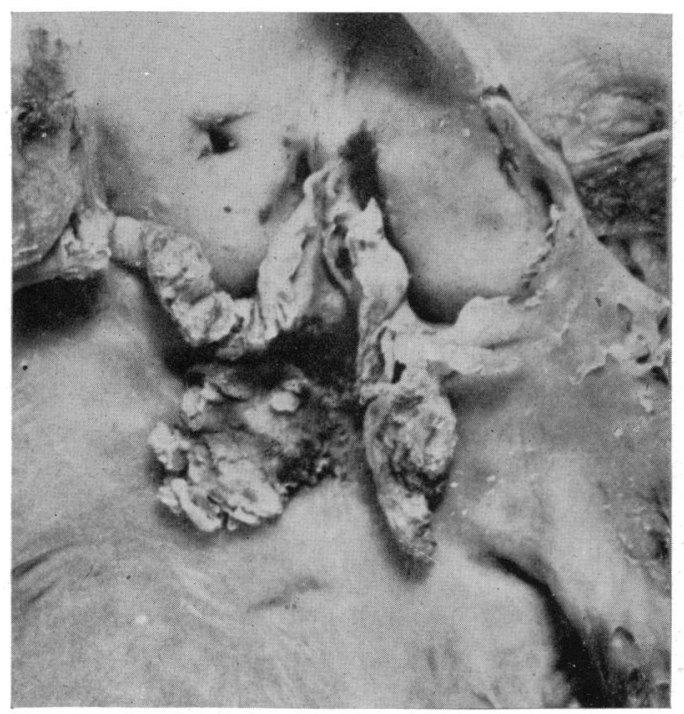

A

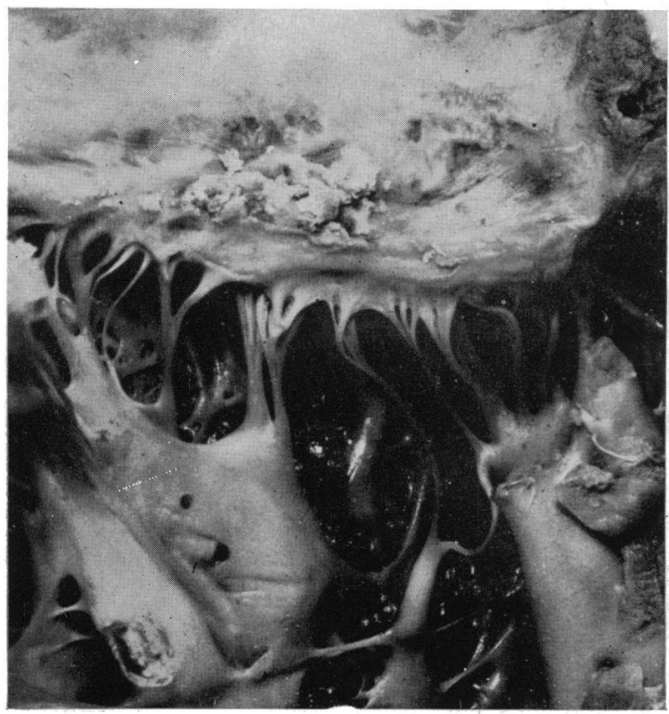

C

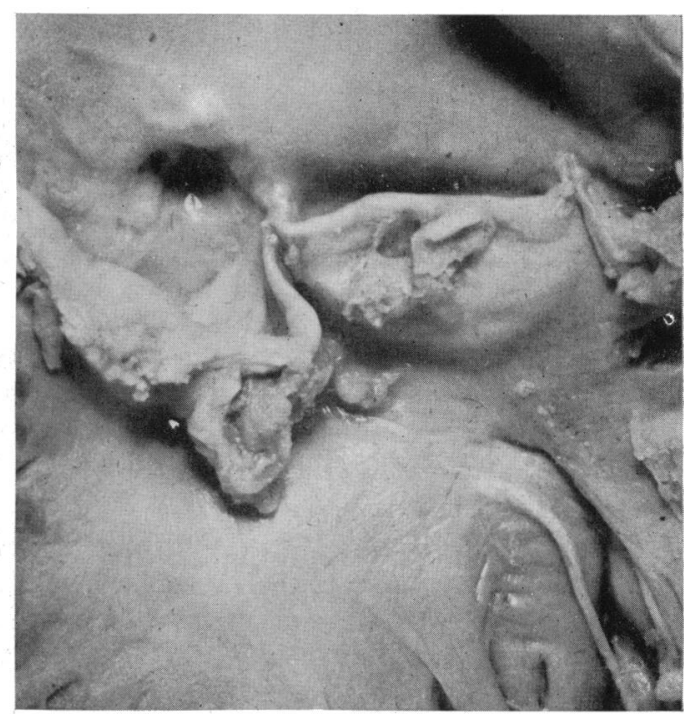

B

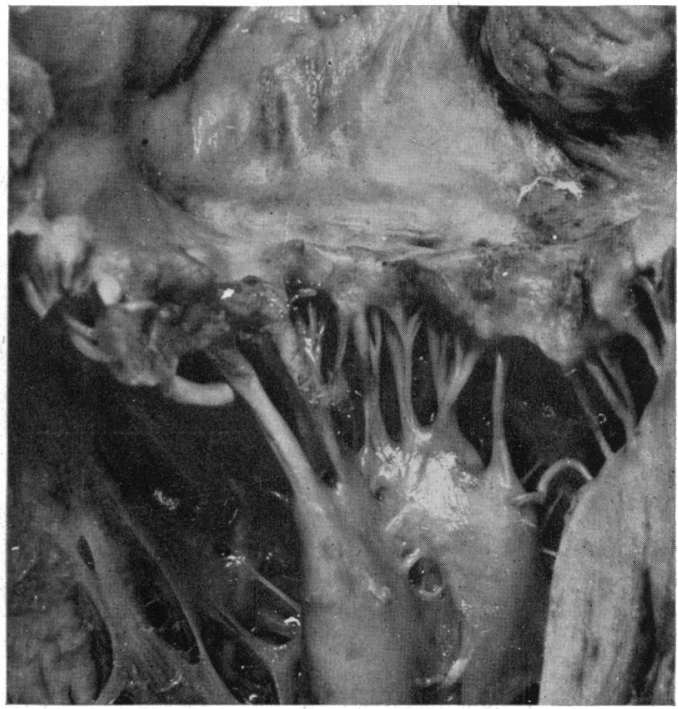

D

Fig. 9.-Healing of vegetations after treatment. (A) Case 9, aortic valve. Death on fifteenth day of treatment; histologically indistinguishable from untreated case (Stage 1). (B) Case 28, aortic valve. Death four days after treatment; vegetations histologically healing (Stage 2). (C) Case 9, mitral valve. Vegetations histologically healing (Stage 2). Compare with unhealed lesion on aortic valve of same case (A). (D) Case 7, mitral valve. Death thirteen weeks after completion of treatment. Vegetations almost completely healed histologically (Stage 3 ). 
in spite of the sterile blood culture during life, Strept. viridans was isolated from the vegetations after death. This type of case, in which a sterile blood culture can be obtained although living organisms are present in the vegetations, has been previously described by Meads et al. (1945); it probably represents an early stage in the response to penicillin and may explain the need to continue treatment long after the blood is sterile.

In Cases 9, 12, and 23, we cannot regard the infection as controlled, but there was some response to treatment in Case 12; this supports the suggestion recently made by Gordon and Zinnemann (1945) that some strains of Hamophilus influenza are sensitive in vitro to high concentrations of penicillin. In the other two dying during treatment (Cases 25 and 30) the infection appeared clinically controlled and the vegetations were sterile at necropsy, but there was no histological evidence of healing.

Eight cases died after treatment; in all the infection had been clinically controlled and cultures of the vegetations, made in four, were sterile. Evidence of healing was present in all the six examined histologically, and was more advanced in those who lived longest after treatment.

Thus, of 13 cases dying after the first week of treatment, there is evidence of failure to control the infection in only 3 ; one of these showed some response clinically, and none completed a full course before death. Histological evidence of healing was not present until some time after clinical control of infection and sterilization of the valves, and did not reach an advanced stage until the infection had been clinically controlled for three months.

\section{Causes of Death}

Since in most of our cases death cannot be attributed directly to the infection, other adequate causes of death should be demonstrable and this proved to be so: heart failure, uræmia, or vascular accidents were the usual immediate causes (Fig. 10). In Table $X$ the clinical causes of death are compared with the post-mortem findings in 13 cases. Infection was a direct cause of death only when the patient died during treatment and major embolic

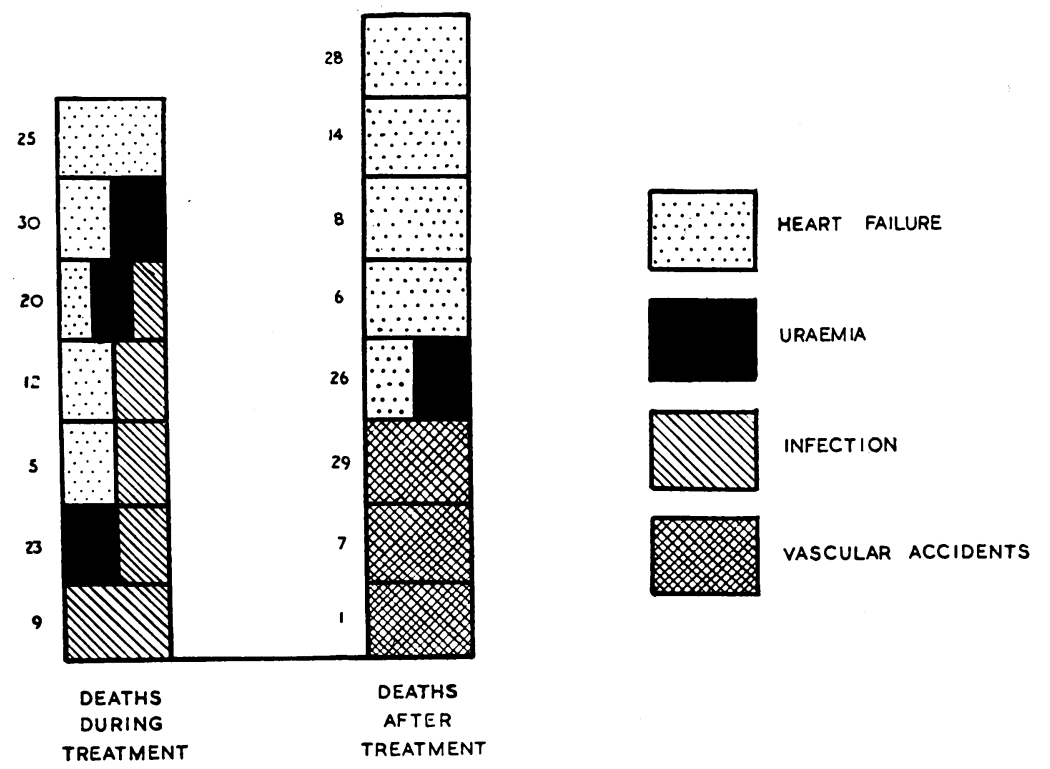

Fig. 10.-Diagram showing clinical causes of death in 15 cases. When more than one factor appeared important, all have been represented. 
accidents led to death only in those surviving treatment. Heart failure and uræmia occurred in both groups.

Heart failure was the most important cause of death for of 18 cases without failure only 2 died, whereas of 15 with failure 13 died; in 5 of these heart failure was the sole cause of death, in 5 it was a major factor, but in 3 failure was not severe when death occurred from other causes.

TABLE $X$

Causes of Death

\begin{tabular}{|c|c|c|c|}
\hline Case & $\begin{array}{l}\text { Time of } \\
\text { death }\end{array}$ & Clinical cause of death & Principal post-mortem findings \\
\hline 5 & $\begin{array}{l}\text { During } \\
\text { treatment } \\
\text { 6th day }\end{array}$ & 1. Left heart failure. 2. ? Infection. & \multirow{5}{*}{ 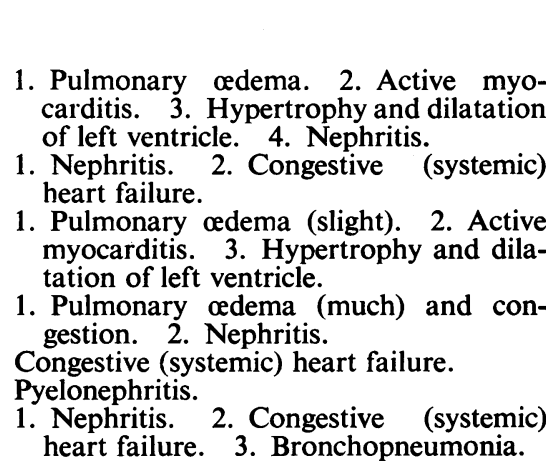 } \\
\hline 20 & 6th day & $\begin{array}{l}\text { 1. Uræmia. 2. Right heart failure. } \\
\text { 3. ? Infection. }\end{array}$ & \\
\hline 9 & 15th day & Infection. & \\
\hline 12 & 20th day & 1. Acute left heart failure. 2. ? Infection. & \\
\hline $\begin{array}{l}25 \\
23 \\
30\end{array}$ & $\begin{array}{l}\text { 20th day } \\
27 \text { th day } \\
27 \text { th day }\end{array}$ & $\begin{array}{l}\text { Left heart failure leading to right. } \\
\begin{array}{l}\text { 1. Uræmia. 2. Infection. } \\
\text { 1. Uræmia. 2. Right heart failure. }\end{array}\end{array}$ & \\
\hline 28 & $\begin{array}{l}\text { After } \\
\text { treatment } \\
4 \text { days }\end{array}$ & Acute left heart failure. & $\begin{array}{l}\text { 1. Pulmonary odema (moderate) and con- } \\
\text { gestion. 2. Active myocarditis. 3. Hy- } \\
\text { pertrophy and dilatation of left ventricle. }\end{array}$ \\
\hline $\begin{array}{r}8 \\
29\end{array}$ & $\begin{array}{l}4 \text { weeks } \\
4 \text { weeks }\end{array}$ & $\begin{array}{l}\text { Left heart failure leading to right. } \\
\text { Cerebral hæmorrhage }\end{array}$ & $\begin{array}{l}\text { No necropsy. } \\
\text { Cerebral hæmorrhage. }\end{array}$ \\
\hline $\begin{array}{r}1 \\
14\end{array}$ & $\begin{array}{r}6 \text { weeks } \\
10 \text { weeks }\end{array}$ & $\begin{array}{l}\text { Pulmonary infarction. } \\
\text { Left heart failure leading to right. }\end{array}$ & $\begin{array}{l}\text { Pulmonary infarction. } \\
\text { 1. Congestive (systemic) heart failure. }\end{array}$ \\
\hline & & & $\begin{array}{l}\text { 2. Pulmonary oedema (slight) and con- } \\
\text { gestion. 3. Peritonitis. }\end{array}$ \\
\hline 26 & 10 weeks & $\begin{array}{l}\text { 1. Uræmia. 2. Left heart failure leading } \\
\text { to right. 3. Acute hepatitis. }\end{array}$ & No necropsy. \\
\hline 6 & 13 weeks & Left heart failure leading to right. & $\begin{array}{l}\text { 1. Congestive (systemic) heart failure. } \\
\text { 2. Bronchopneumonia. }\end{array}$ \\
\hline 7 & 13 weeks & $\begin{array}{l}\text { 1. Cerebral hæmorrhage. 2. Pulmonary } \\
\text { embolism from femoral venous throm- } \\
\text { bosis. }\end{array}$ & $\begin{array}{l}\text { 1. Cerebral hæmorrhage. 2. Pulmonary } \\
\text { embolism and femoral venous throm- } \\
\text { bosis. }\end{array}$ \\
\hline
\end{tabular}

Heart failure usually developed when considerable cardiac enlargement was present (Table XI) and it is interesting to consider the factors upon which the size of the heart depended. The size before infection is naturally a factor but, unfortunately, we generally have no record of this. As we have shown, the progress of the infection leads to a progressive increase in the heart size in all those where we have data bearing on the point. It is, therefore, to be expected that the longer the infection has been present the larger the heart will be; on comparing the heart size before treatment with the duration of the illness (Table XI) it was found that of 7 patients with car diohoracic ratios of 1.5 or less, 6 had suffered from symptoms of infection for fifteen or more weeks and 6 had heart failure, whereas of 8 without cardiac enlargement, only 1 had been ill for more than fifteen weeks. This direct relation between the dura- 
tion of the bacterial endocarditis and the heart size suggests that cardiac damage owing to the infection plays an important part in producing cardiac enlargement and heart failure.

Myocardial lesions and valvular damage may both be important in the production of cardiac enlargement and heart failure in untreated bacterial endocarditis. The inflammatory and embolic myocardial lesions have been studied in the untreated disease by Bracht and Wachter (1909), Saphir (1935), and De Navasquez (1939). Small coronary emboli, structurally similar to the vegetations, appear to be common histologically; De Navasquez (1939) demonstrated such lesions in 16 of his 20 untreated cases. The lesions studied by Bracht and Wachter (1909) led to destruction of muscle tissue and some healing took place in the untreated disease.

TABLE XI

Comparison of Heart Size, Incidence of Heart failure, Death, and Duration of Infection

\begin{tabular}{|c|c|c|c|c|c|}
\hline \multicolumn{2}{|c|}{$\begin{array}{l}\text { Cardiothoracic } \\
\text { ratios }\end{array}$} & $\begin{array}{l}\text { Number of } \\
\text { cases }\end{array}$ & $\begin{array}{c}\text { Number with } \\
\text { heart } \\
\text { failure }\end{array}$ & $\begin{array}{l}\text { Number of } \\
\text { deaths from } \\
\text { heart failure }\end{array}$ & $\begin{array}{l}\text { Number with } \\
\text { symptoms of } \\
\text { infection for } 15 \\
\text { or more weeks }\end{array}$ \\
\hline $\begin{array}{l}2.0 \text { or more } \\
1.9 \text { or } 1.8 \\
1.7 \text { or } 1.6 \\
1.5 \text { or less }\end{array}$ & $\begin{array}{l}\cdots \\
\cdots \\
\cdots \\
\cdots\end{array}$ & $\begin{array}{l}8 \\
7 \\
6 \\
7\end{array}$ & $\begin{array}{l}1 \\
1 \\
4 \\
6\end{array}$ & $\begin{array}{l}0 \\
1 \\
2 \\
6\end{array}$ & $\begin{array}{l}1 \\
2 \\
3 \\
6\end{array}$ \\
\hline Totals & .. & $28^{*}$ & 12 & 9 & 12 \\
\hline
\end{tabular}

* Five cases, unfit for cardioscopy, omitted.

The histology of the myocardium has been examined in 13 of our cases; our examination was not exhaustive for routine sections were taken only from a standard site in the ventricular septum though sometimes additional sections from other parts of the myocardium were examined. Fibrotic and inflammatory lesions were present in 9; these were severe in 5 cases. Libman and Friedberg (1942) were inclined to minimize the importance of myocardial lesions, but heart failure was a principal cause of death in 4 or our 5 cases with severe lesions whereas this was true of only half of those with slight lesions or no lesion. Although these figures are not incompatible with the contention of Buchbinder and Saphir (1939) that myocardial lesions play an important part in the production of heart failure, there can be little doubt that valvular damage is often more important as Bloomfield et al. (1945), Bloomfield and Halpern (1945), and Rosenblatt and Loewe (1945) found in their cases. In our Case 25 the blood pressure suddenly altered from $140 / 90$ to $145 / 55$ owing to rupture of an aortic cusp three days before treatment; this led to heart failure and a change in the cardiothoracic ratio from 1.8 to $1 \cdot 4$. Death occurred 23 days later and the valve perforation was confirmed at necropsy. Since the infection frequently attacks the aortic valve, failure will often be associated with aortic incompetence, as Mokotoff et al. (1946) showed. Of our 29 cases with rheumatic heart disease, 16 had aortic incompetence on admission and 10 of these developed failure; 2 others developed aortic incompetence under our observation and failure followed in both, whereas heart failure occurred in only 2 of 11 without aortic incompetence. If damage to the aortic valve by the infection is an important cause of failure, we should expect left heart failure to be common. Excluding one case in which failure was associated with a congenital lesion, left heart failure was present in 10 of our cases and was followed by right heart failure in 6 ; 9 of these had aortic incompetence. In 3 right heart failure was present on admission; all 3 had aortic incompetence and we cannot be certain that left heart failure had not been 
present in the earlier stages, but there was no history of paroxysmal dyspnœa. In the remaining case right heart failure developed during treatment.

In short, heart failure was present in nearly half and was a principal cause of death in two-thirds of those that were fatal. Recovery was uncommon in those with failure and the rule in those without it. Heart failure occurred principally after long-standing infection and was generally associated with much cardiac enlargement and aortic incompetence; it was usually left-sided at the onset. Both myocardial and valvular damage due to the infection were probably factors in producing failure but the valvular lesions played the more important part. As most of our patients had only slight cardiac lesions before the infection, we consider that the cardiac damage due to the infection played a more important part than the underlying congenital or rheumatic lesion in causing failure. Since the infection usually attacks the aortic valve, the frequency of left heart failure and its association with aortic incompetence support this contention.

Renal Damage. Impairment of renal function was found clinically in 10 cases; in one other no renal function tests were made before death on the sixth day of treatment but at necropsy a severe nephritis was present. Renal impairment never appeared for the first time during or after treatment. As Levy and McKrill (1946) found, the longer the duration of infection the greater the proportion of patients with severe renal damage (Table XII).

TABLE XII

Comparison of Duration of Symptoms with Renal Impairment and with Number of Deaths

\begin{tabular}{|c|c|c|c|c|c|c|}
\hline \multicolumn{4}{|c|}{ Duration of symptoms of infection } & \multirow{2}{*}{$\begin{array}{c}\text { Number of cases } \\
7 \\
13 \\
7 \\
6\end{array}$} & \multirow{2}{*}{$\begin{array}{c}\begin{array}{c}\text { Number with } \\
\text { impaired renal } \\
\text { function }\end{array} \\
1 \\
4 \\
3 \\
3\end{array}$} & \multirow{2}{*}{$\begin{array}{c}\text { Number of deaths } \\
0 \\
4 \\
5 \\
6\end{array}$} \\
\hline $\begin{array}{l}\text { Less than } 10 \text { weeks. } \\
10-19 \text { weeks. } \\
20-29 \text { weeks. . } \\
30 \text { or more weeks . }\end{array}$ & $\begin{array}{l}\cdots \\
\cdots \\
\cdots\end{array}$ & $\begin{array}{l}\cdots \\
\cdots \\
\cdots\end{array}$ & $\begin{array}{l}\cdots \\
\cdots \\
\cdots\end{array}$ & & & \\
\hline
\end{tabular}

Of these 11 patients with severe renal damage only 2 recovered; in one case the standard urea clearance was 19 per cent on admission and the blood urea $104 \mathrm{mg}$. per 100 c.c.; during the third week of treatment the figures were 68 per cent and $48 \mathrm{mg}$. per 100 c.c. and two weeks after treatment the urea clearance was 96 per cent and the blood urea $34 \mathrm{mg}$. per 100 c.c. In the other case the initial urea clearance was 40 per cent and the blood urea $42 \mathrm{mg}$. per 100 c.c.; during treatment the blood urea rose to $64 \mathrm{mg}$. but eight weeks after treatment it was $26 \mathrm{mg}$. and the urea clearance 86 per cent. Renal function also improved in 2 of the 9 fatal cases; in 4 no serial data are available, and in 3 the renal impairment increased before death. Four died in uræmia with final blood urea levels of 484, 220, 152, and $148 \mathrm{mg}$. per 100 c.c.; additional possible causes of death were present in all (Fig. 10).

It was possible to study the renal histology in 11 of 15 fatal cases; the clinical and histological findings are summarized in Table XIII. In 4 of these 11 there was severe, and in 2 slight impairment of renal function before death, but none had hypertension during life. All the 4 with severe impairment of renal function had a severe nephritis histologically, as did one without renal function tests during life. In 4 cases this was a diffuse glomerular nephritis, 2 acute and 2 subacute, and in 1 pyelonephritis was found. In the 2 with slight impairment of renal function the only lesion was glomerular fibrosis not unlike that described by Bell (1932) in untreated subacute bacterial endocarditis; this was also present in 5 others and 2 of these were known to have no clinical impairment of renal function. In 2 there was increased intercapillary hyaline material similar to that found by Ellis (1942) in his Type II nephritis; neither had nitrogen retention during life. The typical focal glomerular necroses of embolic 
nephritis were present in only 2 cases and these changes were limited to a few glomeruli. The renal histology thus showed a variety of changes and was characterized by the frequency of diffuse glomerular lesions, whereas focal embolic lesions were uncommon.

TABLE XIII

Kidneys-Clinical and Histological Findings. (11 Cases)

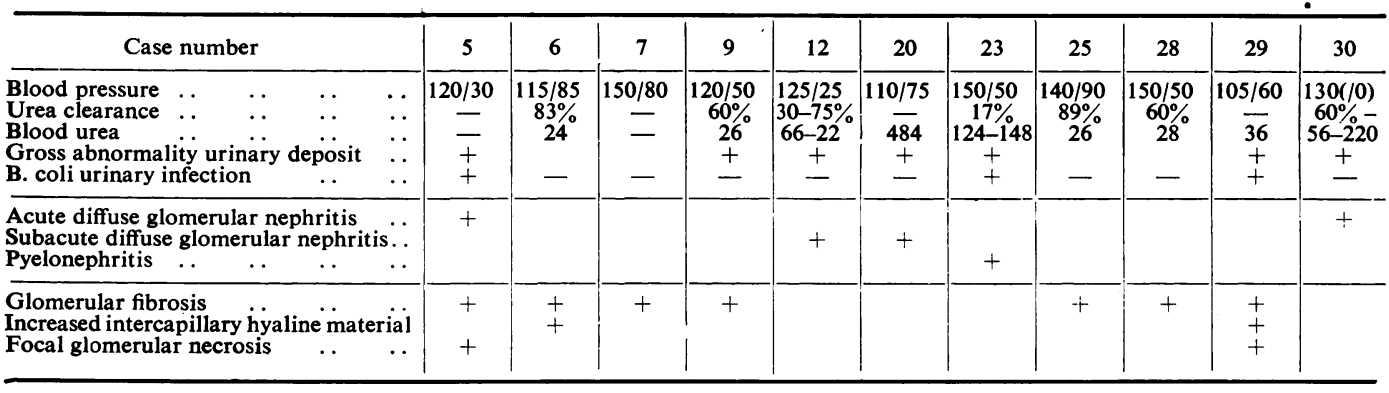

Libman and Friedberg (1942) described diffuse glomerular nephritis in untreated bacterial endocarditis and found it more frequently in the bacteria-free stage. They considered that it led to progressive renal impairment and death from uræmia in at least one-third of their cases dying in the bacteria-free stage and remarked on the absence of hypertension, unless present before the nephritis. Loewe and Rosenblatt (1945) recorded one case, unsuccessfully treated with penicillin, with diffuse glomerular nephritis but no focal glomerular lesions; the blood pressure was 120/80, and later 120/40.

Thus diffuse glomerular lesions, without hypertension, occur not infrequently in bacterial endocarditis. The presence of gross renal insufficiency in 2 of our recovering cases, and the improvement of renal function in 2 of our unsuccessful cases, suggests that similar types of renal damage may be compatible with recovery after penicillin therapy. If this is so, it is possible that when renal function is impaired during the active stage, progressive renal insufficiency may develop long after successful treatment; a long-term study of recovering cases with past renal impairment should decide this.

Major Embolic Accidents. There were 21 patients with major embolic accidents, 17 before treatment, 8 during treatment, and 4 after treatment; the sites of lodgement were pulmonary in 6 , cerebral in 7 , renal in 8 , splenic in 7 , retinal in 3 , and coronary in 1 case. The smaller number of major emboli during treatment is of little significance since the period of treatment was short compared with the duration of infection before treatment, but it is clear that major emboli are rare after treatment; if we exclude the 3 with cerebral or subarachnoid hæmorrhage in which embolization may have occurred some time previously, major emboli occurred after treatment in only one, who were never fully treated (Case 1).

One of the cases with cerebral hæmorrhage is interesting. Following a cerebral embolus nine months before treatment, she developed a left-sided hemiparesis which almost completely recovered; three months after the end of treatment, while apparently well, she suddenly collapsed unconscious with a severe left hemiplegia; she died five days later. At necropsy, a cerebral hæmorrhage had largely destroyed the right lenticular nucleus and internal capsule. It seems likely that the cerebral embolus led either to a mycotic aneurysm or to an area of softening but, owing to the disorganization of the affected area at necropsy, we were unable to determine which of these had caused the hæmorrhage. Cerebral embolism, with apparent recovery, may thus lead to fatal cerebral hæmorrhage many months after the infection is controlled.

Major emboli may occur at any stage of the disease; 3 of the 31 major emboli marked the onset of symptoms of infection, 11 occurred in the first ten weeks of the illness, 9 in the second ten weeks, and 8 subsequently. 


\section{SPECIAL TyPeS OF CASE}

Associated with Pregnancy. In 7 of our 22 female cases the infection began during pregnancy (Table XIV); this is a remarkably large number for Page and Campbell (1939) were able to find records of only 15 cases of subacute bacterial endocarditis associated with pregnancy when they published their own 3 cases. In the first, two diagnosis was delayed: one of these was moribund on admission and died six days later; in the other the infection was controlled but death occurred three months after treatment from cerebral hæmorrhage. The other five were treated early and did well in spite of major vascular accidents in two and heart failure in one. Six children are well but in one case a macerated fœtus was expelled a few days before the beginning of treatment.

TABLE XIV

Cases Associated with Pregnancy

\begin{tabular}{|c|c|c|c|c|c|c|c|}
\hline Case & Age & $\begin{array}{l}\text { Stage of } \\
\text { pregnancy } \\
\text { at onset }\end{array}$ & $\begin{array}{l}\text { Time } \\
\text { before } \\
\text { treatment }\end{array}$ & Confinement & Child & Mother & Remarks \\
\hline $\begin{array}{l}5 \\
7 \\
3\end{array}$ & $\begin{array}{l}26 \\
23 \\
19\end{array}$ & $\begin{array}{c}\text { Term } \\
\text { Term } \\
33 \text { weeks }\end{array}$ & $\begin{array}{l}28 \text { weeks } \\
46 \text { weeks } \\
10 \text { weeks }\end{array}$ & $\begin{array}{l}\text { Normal } \\
\text { Normal } \\
\text { Normal }\end{array}$ & $\begin{array}{l}\text { Well } \\
\text { Well } \\
\text { Well }\end{array}$ & $\begin{array}{l}\text { Died } \\
\text { Died } \\
\text { Well }\end{array}$ & $\begin{array}{l}\text { Regarded as puerperal pyrexia. } \\
\text { Regarded as puerperal pyrexia. } \\
\text { Coronary embolism during }\end{array}$ \\
\hline 10 & 22 & 20 weeks & 6 weeks & $\begin{array}{l}\text { Cæsarean } \\
\text { section }\end{array}$ & Well & Well & $\begin{array}{l}\text { Subarachnoid hæmorrhage at } \\
\text { 34th week. }\end{array}$ \\
\hline 18 & 28 & 20 weeks & 5 weeks & $\begin{array}{l}\text { Forceps for 2nd } \\
\text { stage delay }\end{array}$ & Well & Well & $\begin{array}{l}\text { Blood culture: negative 24th } \\
\text { week, positive } 25 \text { th week. }\end{array}$ \\
\hline 27 & 23 & 32 weeks & 11 weeks & Normal & Well & Well & $\begin{array}{l}\text { Dental extraction 23rd week } \\
\text { pregnancy. }\end{array}$ \\
\hline 31 & 29 & 23 weeks & 5 weeks & $\begin{array}{l}\text { Abortion } 28 \\
\text { weeks }\end{array}$ & Macerated & Well & $\begin{array}{l}\text { Admitted for heart failure; } \\
\text { pyrexia; culture positive. }\end{array}$ \\
\hline
\end{tabular}

Thus, provided the infection is promptly detected and adequately treated, the prognosis is good for mother and child. As these patients are usually under supervision, owing to the association of heart disease with pregnancy, the opportunity for early diagnosis is not lacking. Since confinement may have to be undertaken during the difficult period of convalescence, when the heart is unfit to carry additional burdens, it may be advisable to eliminate the physical strain of labour by Cæsarean section, particularly if there is likely to be any obstetrical difficulty.

With Patency of the Ductus Arteriosus. One of our patients, a girl of 13, had a patent ductus arteriosus infected by a pneumococcus. She had suffered from lassitude and pyrexia for three months before admission, and was then emaciated, very toxæmic, and severely dyspnœic owing to multiple pulmonary infarcts. The infection was controlled by a 28 -day course of penicillin and her general condition improved, but she developed a left pneumothorax (Fig. 11), possibly from rupture of a septic subpleural infarct. Her subsequent progress was satisfactory and four months after treatment the ductus was ligated by Mr. Graham Bryce. Penicillin cover was used and there were no post-operative complications. After operation the heart decreased in size (Fig. 11).

Ligation of the infected ductus has given surprisingly good results (Shapiro and Keys, 1943; Tubbs, 1944; Gilchrist, 1945) but the success of penicillin in controlling the infection makes it possible to treat the infection first and, when the condition of the patient has improved, to ligate the ductus. Vesell and Kross (1946) have reported a successful case in which the ductus was ligated six days before the end of a 30-day course of treatment. They suggest 
immediate operation if the organism is insensitive or the duration of infection more than three months or the response to penicillin doubtful. We do not yet know how often penicillin will control infection in a patent ductus but the general condition of our patient on admission excluded chest surgery and the ultimate result justified the attempt to control the infection by penicillin before contemplating surgical ligation of the ductus. If the infection of the ductus can be arrested by penicillin, this will lead to such improvement that the risk of subsequent surgical intervention will be materially diminished. We, therefore, consider that this method of management should receive adequate trial.

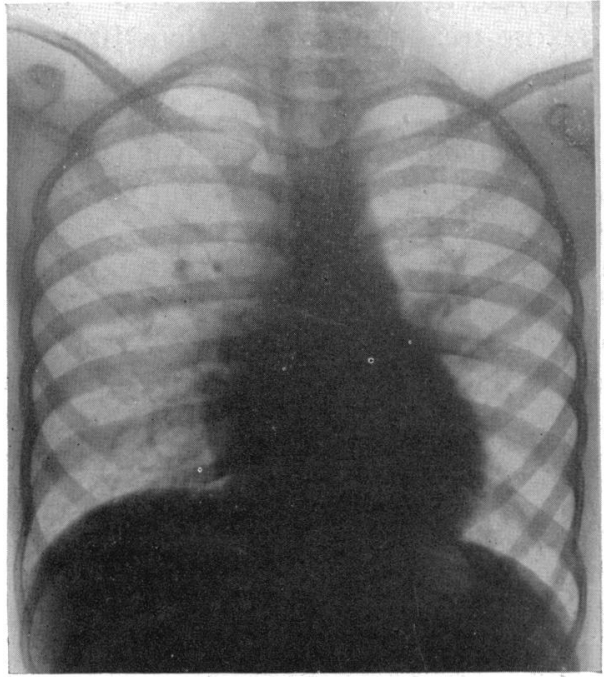

A

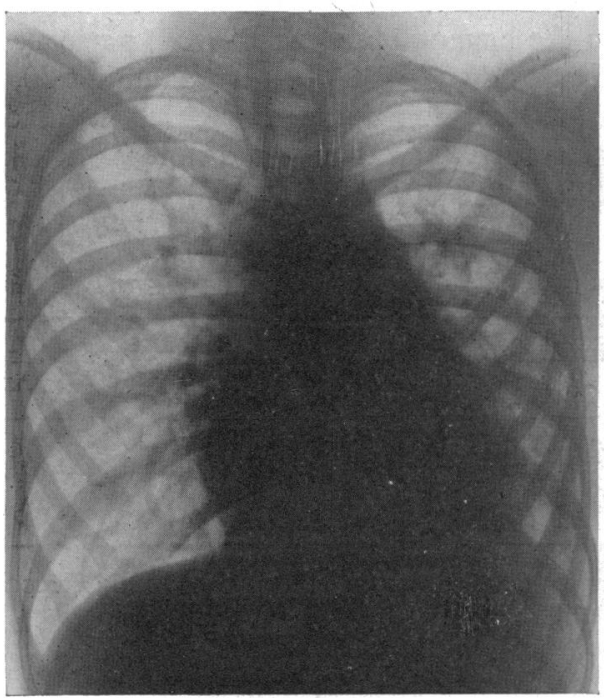

$\mathrm{C}$

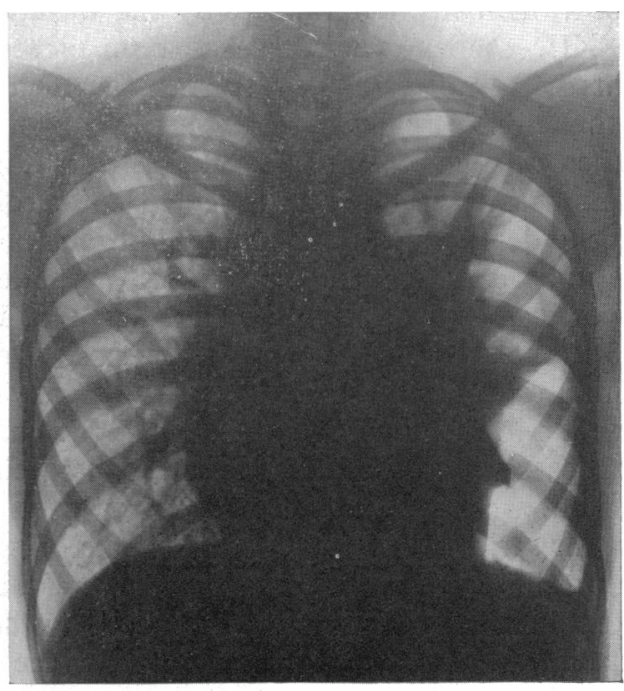

B

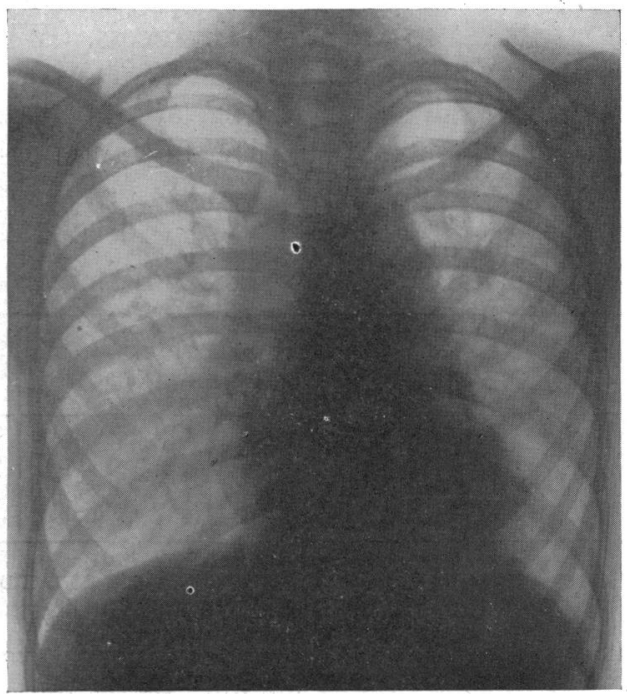

$\mathrm{D}$

FIG. 11.- Infected patent ductus: Teleradiograms. Case 33. (A) Two months before treatment. (B) Fourth week of treatment, showing left pneumothorax and cardiac enlargement. (C) Three months after treatment and one month before ligation of ductus, showing absorption of pneumothorax but persistence of cardiac enlargement. (D) Two months after ligation of patent ductus, showing decrease of heart size. 


\section{Prognosis}

Although failure to control the infection has rarely been a hindrance to success, yet nearly half our patients died. With such a means of arresting the disease in our hands we cannot be satisfied with this mortality and must seek to reduce it. Although we have studied only a small series, much evidence has been presented to indicate that the longer the duration of the infection the larger the heart, the more frequent renal impairment, and the more often do heart failure and uræmia prevent recovery. It is, therefore, to be expected that the mortality will be principally determined by the duration of infection; this has been illustrated in Table XII. When symptoms had been present before treatment for less than 10 weeks no patient died; none with symptoms for 30 or more weeks recovered and only two with symptoms for 20 or more weeks.

When we come to consider other factors it is more difficult to draw conclusions. It seems reasonable to suppose that the severity of cardiac damage before infection will play a part in leading to death when the additional burden of infection is added but, if we judge the severity of the underlying cardiac lesion from the patients' capacity for exertion before infection, no clear correlation with mortality emerges - 6 of 17 cases in Class I died, 8 of 13 in Class II, and 1 of 3 in Class III. Unfortunately the last group with much reduced capacity for effort is too small to be useful, and the mortality may not be significantly higher in the intermediate group than in the apparently fit. Since the underlying heart disease was comparatively slight in most cases, it may be unimportant compared with the severe damage that may occur when the infection remains untreated for months.

In this series all patients over 50 years of age died, but there was no relation between age and mortality in the younger age groups. On comparing the number of deaths in each group with the duration of symptoms of infection it became clear that the mortality was determined by the duration of symptoms and not by the age. This is confirmed by the fact that two patients over 50 years of age, treated subsequent to this series, have both made good recoveries.

Factors such as the heart size (see Table XI) and the hæmoglobin level before treatment can be attributed to the infective process. When the hæmoglobin was over 70 per cent 2 of 9 cases died; - when it was between 50-69, 9 of 16 cases died; and when it was under 50, 4 of 8 cases died. The degree of correlation between heart size on the hæmoglobin level and the mortality may be merely another indication of the severity and duration of infection.

TABLE XV

Comparison of Resistance and Number of Organisms With Number of Deaths

\begin{tabular}{|c|c|c|c|c|c|c|c|c|}
\hline \multicolumn{3}{|c|}{ Resistance* } & \multirow{2}{*}{$\begin{array}{c}\begin{array}{c}\text { Number of } \\
\text { cases }\end{array} \\
\begin{array}{r}9 \\
20 \\
3\end{array}\end{array}$} & \multirow{2}{*}{$\begin{array}{c}\begin{array}{c}\text { Number of } \\
\text { deaths }\end{array} \\
4 \\
9 \\
2\end{array}$} & \multicolumn{2}{|c|}{$\begin{array}{c}\text { Number of organisms } \\
\text { per c.c. blood }\end{array}$} & \multirow{2}{*}{$\begin{array}{c}\begin{array}{c}\text { Number of } \\
\text { cases }\end{array} \\
6 \\
9 \\
9\end{array}$} & \multirow{2}{*}{$\begin{array}{c}\begin{array}{c}\text { Number of } \\
\text { deaths }\end{array} \\
4 \\
1 \\
5\end{array}$} \\
\hline $\begin{array}{l}\text { Less than } 1 \\
1-5 \\
\text { Over } 5 \ldots\end{array}$ & $\begin{array}{l}\cdots \\
\cdots \\
\cdots\end{array}$ & $\begin{array}{l}\cdots \\
\cdots \\
\cdots\end{array}$ & & & $\begin{array}{ll}\text { Less than } & 25 . \\
25-100 & \\
101-1000 & \ldots\end{array}$ & & & \\
\hline
\end{tabular}

* The resistance of the organism is expressed as a multiple of the resistance of the Oxford staphylococcus.

Provided the causative organism is sensitive to penicillin, neither the estimated degree of resistance to penicillin nor the number of organisms per c.c. of blood appear to be related to the mortality (Table XV). The importance of the resistance of the organism may be masked by the inaccuracy of the method of measurement, or the resistance may be truly unimportant up to a point, since the level of penicillin in the blood probably allows a safe margin unless the organism is insensitive. 
With a much larger series it may prove justifiable to attach greater importance to some of these factors, but in our cases we are convinced of the importance of only one: the duration of the infection before treatment. This is, fortunately, a factor we can influence by early diagnosis and prompt treatment; if this can be achieved the present mortality should be materially reduced.

Failure of the patient to seek medical advice in the early stages is a most serious obstacle to the early diagnosis of some diseases, but this does not appear to be so in subacute bacterial endocarditis, for nearly three-quarters of our patients (24) were either under regular supervision for their heart disease at the onset of symptoms of infection, or sought medical advice when the first symptoms appeared. Of the other 9 only 4 delayed more than four weeks before seeking advice. The mortality is, therefore, closely related to the period under medical observation. If the disease had been suspected when these patients first sought advice, repeated blood culture by an adequate technique would have established the diagnosis, for, even with infections of short duration, we had no difficulty in isolating the organism. In these early cases non-specific symptoms predominate and signs are few; if penicillin treatment is to be successful the diagnosis must be suspected before the classical physical signs appear, for they indicate that the disease is well advanced and should serve as a warning that arrest of the infection may not avert death from heart failure or uræmia.

\section{SUMMARY}

The treatment of subacute bacterial endocarditis by penicillin is described in 33 unselected cases with 15 deaths; the minimum period of observation after the completion of treatment was six months.

The clinical features of these cases, the methods of investigation, and the technique of laboratory procedures are described.

The clinical response to adequate treatment is described and the importance of careful management during convalescence is emphasized.

The degree of recovery is assessed in 18 successful cases; although most patients resume their old occupations, increased residual cardiac damage is the rule and a small proportion may develop stenotic valvular lesions during healing.

Relapses following inadequate therapy, if promptly detected and adequately treated, do not appear to prejudice the ultimate outcome.

The clinical and pathological evidence indicating control of the infection in unsuccessful cases is assessed; it is concluded that the infection was controlled in all cases completing treatment.

The process of healing is studied histologically in 12 cases: healing is not advanced until three months after clinical control of the infection.

The causes of death in 15 cases are discussed with a description of the post-mortem findings in 13 cases. The importance of heart failure in causing death is emphasized. Cardiac damage by the infection is the important cause of failure.

The renal lesions are studied histologically in 11 cases: diffuse, not focal; glomerular lesions predominate; and it is concluded that, if similar lesions occur in successful cases, they may lead to future renal insufficiency.

Seven cases associated with pregnancy are recorded; 5 mothers and 6 children survived.

In one case with an infected patent ductus arteriosus the ductus was ligated four months after successful penicillin treatment.

The factors that may have played a part in the outcome of treatment are discussed; evidence 
is presented indicating that the duration of the infection before treatment is of the greatest importance. Reduction of the present mortality will, therefore, be most readily achieved by earlier diagnosis and treatment.

This investigation was under the general direction of Professor Crighton Bramwell and Professor $\mathbf{H}$. B. Maitland; to them, and to Professor S. L. Baker, Dr. R. W. Fairbrother, and Professor R. Platt, we are indebted for helpful advice. In the earlier cases certain of the bacteriological investigations were undertaken in Professor Maitland's Department. We are indebted to Dr. E. Duff Gray for the radiograms. We gratefully acknowledge the willing co-operation of the House Physicians and of the staffs of the Clinical Laboratory and the Department of Pathology.

\section{REFERENCES}

Anderson, D. G., and Keefer, C. S. (1945). Med. Clin. North America, 29, 1129.

Bell, E. T. (1932). Amer. J. Path., 8, 639.

Bloomfield, A. L., Rantz, L. A., and Kirby, W. M. M. (1944). J. Amer. med. Assoc., 124, 627. , Armstrong, C. D., and Kirby, W. M. M. (1945). J. clin .Invest., 24, 251.

— and Halpern, R. M. (1945). J. Amer. med. Assoc., 129, 1135.

Bracht, E. and Wachter, -. (1909). Dtsch. Arch. klin. Med., 94, 493.

Buchbinder, W. C., and Saphir, O. (1939). Arch. intern. Med., 64, 336.

Christian, H. A. (1941). J. Amer. med. Assoc., 116, 1048.

Christie, R. V. (1946). Lancet, 1, 369; Brit. med. J., 1, 380.

Criteria for Nomenclature and Diagnosis of Diseases of the Heart (1942). 4th ed., New York Heart Association, New York.

Dawson, M. H., and Hobby, G. L. (1944). J. Amer. med. Assoc., 124, 611.

and Hunter, T. H. (1945). Ibid., 127, 129.

- (1946). Ann. intern. Med., 24, 170.

DeNavasquez, S. (1939). J. Path. Bact., 49, 33.

Duthie, E. S. (1944). Brit. J. exp. Path., 25, 96.

Ellis, A. (1942). Lancet, 1, 1.

Favour, C. B., Janeway, C. A., Gibson, J. G., and Levine, S. A. (1946). New Eng. J. Med., $234,71$.

Flippin, H. F., Mayock, R. L., Murphy, F. D., and Wolferth, C. C. (1945). J. Amer. med. Assoc., $129,841$.

Florey, M. E., and Florey, H. W. (1943). Lancet, 1, 387.

Geiger, A. J., and Goerner, J. R. (1946). New Eng. J. Med., 235, 285.

Gilchrist, A. R. (1945). Brit. Heart J., 7, 1.

Glaser, R. J., Smith, R. O., Harford, C. G., and Wood, W. B. (1946). J. Lab. clin. Med., $31,291$.

Goerner, J. R., Geiger, A. J., and Blake, F. G. (1945). Ann. intern. Med., 23, 491.

Gordan, M., and Zinnemann, K. (1945). Brit. med. J., 2, 795.

Herrell, W. E. (1944). J. Amer. med. Assoc., 124, 622.

-, Nichols, D. R., and Heilman, D. H. (1944). Ibid., 125, 1003.

Hines, L. E., and Kessler, D. L. (1945). Ibid., 128, 794.

Keefer, C. S., Blake, F. G., Marshall, B. K., Lockwood, J. S., and Wood, W. B. (1943). Ibid., $122,1217$. (1944). Ibid., 124, 636. (1945). Ibid., 128, 1163.

Kelson, S. R. (1945). Ann. intern. Med., 22, 75.

Levy, L., and McKrill, N. (1946). Arch. intern. Med., 77, 367.

Libman, E., and Friedberg, C. K. (1942). Subacute Bacterial Endocarditis, London.

Loewe, L. (1945). Canad. med. Assoc. J., 52, 1.

-, Rosenblatt, P., Greene, H. J., and Russell, M. (1944). J. Amer. med. Assoc., $124,144$.

Meads, M., Harris, H. W., and Finland, M. (1945). New Eng. J. Med., 232, 463.

Mokotoff, R., Brams, W., Katz, L. N., and Howell, K. M. (1946). Amer. J. med. Sci., $211,395$.

Page, E. W., and Campbell, J. V. (1939). Amer. J. Obstet. Gynac., 38, 97.

Paullin, J. E., and McLoughlin, C. J. (1945). Ann. intern. Med., 22, 475.

Penfold, J. B.. Goldman, J., and Fairbrother, R. W. (1940). Lancet, 1, 65.

Rosenblatt, P., and Loewe, L. (1945). Arch. intern. Med., 76, 1.

Russek, H. I., Smith, R. H., and Derman, H. (1945). Ibid., 22, 863.

- Smith, R. H., and Zohman, B. L. (1945). Ann. intern. Med., 22, 867.

Sanderson, G., and McEntegart, M. G. (1946). Brit. med. J., 1, 845.

Saphir, O. (1935). Amer. J. Path., 11, 143.

Shapiro, M. J., and Keys, A. (1943). Amer. J. med. Sci., 206, 174.

Tubbs, O.S. (1944). Brit. J. Surg., 32, 1.

Vesell, H., and Kross, I. (1946). Arch. intern. Med., 77, 659.

Ward, G. E. S., Meanock, R. I., Selbie, F. R., and Simon, R. D. (1946). Brit. med. J., $1,383$.

White, P. D., Mathews, M. W., and Evans, E. (1945). Ann. intern. Med., 22, 61.

Wintrobe, M. M., and Landsberg, J. W. (1935). Amer. J. med. Sci., 189, 102. 